\title{
TINJAUAN TEKNOLOGI PROSES EKSTRAKSI BIJIH NIKEL LATERIT
}

\section{Review on Technology of Nickel Laterite Extraction}

\author{
FATHAN BAHFIE ${ }^{1,2 *}$, AZWAR MANAF $^{2 * *}$, WIDI ASTUTI $^{1 * *}$, FAJAR NURJAMAN $^{1 * *}$ dan \\ ULIN HERLINA ${ }^{1 * *}$
}

${ }^{1}$ Balai Penelitian Teknologi Mineral, Lembaga Ilmu Pengetahuan Indonesia Jalan Ir. Sutami Km. 15 Lampung Selatan, Lampung, Indonesia, 35361

2 Departemen Fisika, FMIPA, Universitas Indonesia, Kota Depok, Jawa Barat, Indonesia 16424

Korespondensi e-mail: fathanbahfie@gmail.com/azwar@ui.ac.id

* Kontributor Utama, ** Kontributor Anggota

\begin{abstract}
ABSTRAK
Bijih nikel laterit merupakan mineral yang mengandung senyawa oksida besi-nikel. Teknologi pengolahan nikel laterit secara umum ada 3 metode yaitu hidrometalurgi, pirometalurgi dan reduksi selektif. Hidrometalurgi merupakan metode yang menggunakan pelindian dan larutan seperti asam untuk mengekstraksi nikel laterit. Metode dengan pelindian asam yang bertekanan adalah metode yang paling optimal untuk mendapatkan nikel dengan grade dan recovery tertinggi. Akan tetapi metode ini memiliki dampak pencemaran lingkungan akibat hasil proses pelindian dan waktu yang lama. Metode yang kedua, yaitu pirometalurgi menggunakan temperatur tinggi sampai $1600^{\circ} \mathrm{C}$ sehingga membutuhkan banyak energi seperti proses blast furnace. Metode dengan rotary kiln-electric furnace merupakan metode optimal dalam pengembangan nikel laterit. Akan tetapi kekurangannya yaitu tanpa pemisahan pengotor, energi yang besar, serta masih ada permasalahan teknis seperti adanya material yang mengalami melt partial. Metode yang ketiga yaitu reduksi selektif merupakan proses pemisahan dengan menyeleksi terbentuknya besi oksida sehingga mendapatkan kadar nikel yang tinggi tanpa energi yang tinggi. Hal ini disebabkan adanya penambahan aditif untuk menghambat terbentuknya besi dan menurunkan temperatur reduksi. Metode ini sebagai alternatif pengolahan bijih nikel laterit jenis limonit dan saprolit menjadi konsentrat nikel dengan kadar nikel di atas $5 \%$.
\end{abstract}

Kata kunci: hidrometalurgi, bijih nikel laterit, pirometalurgi, reduksi selektif.

\begin{abstract}
Nickel laterite is a mineral containing iron-nickel oxide compounds. There are three methods for processing nickel laterite, namely hydrometallurgy, pyrometallurgy dan selective reduction. Hydrometallurgy is a method that uses leaching and chemical solutions such as acids to extract nickel laterite. The method with pressure acid leaching is optimal for obtaining the highest grade of nickel and recovery. However, this method has an impact on the environment due to the results of the leaching process in a long time. The second method, pyrometallurgy uses a high temperature up to $1600^{\circ} \mathrm{C}$, so it requires a lot of energy as in the blast furnace process. The rotary kiln-electric furnace method is the optimal method for processing laterite nickel. However, the disadvantages are that the process is without separation of impurities, requires high energy, and there are still technical problems such as the presence of partially melted material. The third method is selective reduction which is the separation process by selecting the formation of iron oxide so it can obtain high-grade nickel without high energy. This is due to the addition of additives to select iron and lower the reduction temperature. This method is an alternative for processing limonite and saprolite nickel laterite ores into nickel concentrates with nickel content above $5 \%$.
\end{abstract}

Keywords: hydrometallurgy, laterite ore, pyrometallurgy, selective reduction. 


\section{PENDAHULUAN}

Nikel adalah logam nonferrous yang penting dan banyak digunakan untuk baja tahan karat dan baja paduan, pelapisan baja, atau katalis dalam proses hidrogenasi industri kimia minyak bumi (Li dkk., 2012; Ma, Cui dan Zhao, 2016). Sumber daya nikel saat ini termasuk bijih nikel sulfida dan bijih nikel laterit, yang masingmasing menyumbang sekitar $30 \%$ dan $70 \%$ dari cadangan nikel dunia. Namun, lebih dari $60 \%$ produksi nikel berasal dari bijih nikel sulfida (Lv $d k k ., 2010)$ karena nikel dalam bijih sulfida dapat dengan mudah diperkaya dan diperoleh kembali dengan flotasi konvensional serta pemisahan magnetik dan gravitasi. Bijih nikel sulfida tingkat tinggi telah dieksploitasi terlebih dahulu dan semakin menipis, maka bijih nikel laterit dengan kadar nikel rendah (Pournaderi $d k k ., 2014)$ secara bertahap menjadi sumber daya utama untuk produksi nikel (Kim $d k k$., 2010; Pickles dkk., 2013; Pickles, Forster dan Elliott, 2014). Nikel dari bijih nikel laterit sebagian besar terjadi pada serpentin dan olivin atau mineral besi oksida yang diperkaya sebagai substitusi isomorfisme sepanjang generasi bijih nikel laterit dari pelapukan batuan ultrabasa (AlKhirbash, 2015; Rice, 2016), sehingga tidak dapat diekstraksi dengan pemisahan konvensional. Selain itu, bijih laterit nikel memiliki kadar nikel yang rendah dan dibagi menjadi tiga lapisan, yaitu limonitik, saprolitik, dan garnieritik (Zevgolis dkk., 2010; Agacayak, Zedef dan Aras, 2016). Sementara, ada dua keuntungan pengembangan yang signifikan untuk bijih laterit nikel yaitu cadangan berlimpah dan endapan terjadi di permukaan sehingga dapat ditambang dari permukaan (Bunjaku dkk., 2012; Pickles dan Elliott, 2015). Oleh karena itu, proses pengolahan yang menguntungkan untuk pemanfaatan bijih nikel laterit yang efisien harus sangat diperhatikan dan diteliti secara mendalam (Elliott, 2015; Ma, Cui dan Zhao, 2016). Ulasan awal oleh Quast $d k k$. (2015) mengatur proses untuk pra-konsentrasi bijih laterit nikel seperti penghilangan fraksi kasar dari umpan, separasi sink-float, pemisahan gravitasi, pemisahan magnetik, pemisahan elektrostatik, dan pengapungan sebelum proses hidrometalurgi dan pirometalurgi ada. Teknikteknik tersebut perlu ada pengembangan untuk memenuhi permintaan dalam peningkatan kadar nikel dan membantu mengeksploitasi bijih nikel laterit lebih efektif. Makalah ini meninjau dan menganalisis pengembangan proses pengolahan bijih nikel laterit dalam beberapa tahun terakhir seperti teknologi rotary kiln-electric furnace, cupola furnace, ppelindian, dan reduksi selektif. Tujuan pengkajian untuk mengetahui proses pengolahan laterit saat ini yang optimal di masa depan.

\section{TINJAUAN UMUM PROSES HIDROMETALURGI PADA PENGOLAHAN BIJIH NIKEL LATERIT}

Proses hidrometalurgi pada pengolahan bijih nikel laterit termasuk pelindian reduksi-amonia, pelindian asam bertekanan, pelindian asam tanpa tekanan, dan pelindian secara bertumpuk. Prinsip dasar pelindian-amonia, pelindian asam bertekanan, dan pelindian asam pada kondisi atmosfer adalah bahwa nikel dan kobalt dalam bijih laterit nikel dapat dipindahkan pada larutan pelindian, yaitu amonia atau asam, karena nikel dan kobalt akan membentuk kompleks dengan amonia atau larut dalam asam.

\section{Proses Caron}

Pelindian ammonia-roasting awalnya didefinisikan sebagai proses Caron. Proses Caron sebagian besar cocok untuk bijih limonit pada temperatur pemanggangan $700-800^{\circ} \mathrm{C}$ dengan reduktor dan penambahan amonium karbonat dari produk yang di-roasting dapat menghasilkan $75-80 \%$ berat Ni dan $40-50 \%$ berat Co. Sheng-li $d k k$. (2010) telah mengoptimalkan kondisi ekstraksi nikel dan kobalt dari bijih laterit berkadar rendah (Ni 1,17\%, Fe 45,56\%) menggunakan metode kombinasi pelindian ammonia-roasting. Kondisi ini menghasilkan fraksi massa reduktor dalam bijih sebesar $10 \%$, waktu pemanggangan 120 menit, temperatur pemanggangan $750-800^{\circ} \mathrm{C}$; dalam proses pelindian amonia, rasio cairan-padatan 4:1 (mL/g), temperatur pelindian $40^{\circ} \mathrm{C}$, waktu pelindian 120 menit, dan rasio konsentrasi $\mathrm{NH}_{3}$ terhadap $\mathrm{CO}_{2} 90 \mathrm{~g} / \mathrm{L}$ dan $60 \mathrm{~g} / \mathrm{L}$. Dalam kondisi optimal, efisiensi pelindian nikel dan kobalt adalah $86,25 \%$ dan $60,84 \%$. Valix dan Cheung (2002) menggunakan unsur sulfur (S) dalam penelitian mereka dan melaporkan bahwa adanya unsur sulfur (S) dapat mengurangi temperatur proses hingga $600^{\circ} \mathrm{C}$ dan juga dapat memberikan recovery $\mathrm{Ni}$ yang lebih tinggi dari bijih limonit dan saprolit. Penambahan 5\% S dalam proses roasting dapat menghasilkan $98 \%$ recovery $\mathrm{Ni}$ dari bijih saprolit dan $80,6 \%$ 
recovery $\mathrm{Ni}$ dari bijih limonit sedangkan tanpa penambahan $\mathrm{S}$ recovery $\mathrm{Ni}$ adalah $28 \%$ dan $29 \%$ masing-masing dari bijih ini pada temperatur $600^{\circ} \mathrm{C}$. Atas dasar proses ini, Ma, Wang, Yang, Yin, dkk. (2013) mengoptimalkannya dengan menambahkan screening sebelum kalsinasi. Sampel bijih yang digunakan adalah laterit kaya besi dengan sejumlah besar besi $(48,3 \%$ berat) dan kadar nikel yang rendah $(1,04 \%$ berat). Tujuan screening adalah untuk menghilangkan beberapa mineral silikat dari bijih laterit limonit. Proses ini meningkatkan ekstraksi nikel dan kobalt dari $84,0 \%$ dan 35,5\% masing-masing menjadi $87,9 \%$ dan 47,4\% (Ma, Wang, Yang, Yin, dkk., 2013). Proses screening juga menguntungkan untuk perolehan komprehensif dan pemanfaatan kandungan besi sehingga meningkatkan kandungan besi dalam residu pelindian hingga $60,7 \%$ tanpa proses tambahan.

\section{Proses Pelindian Asam Bertekanan}

Mekanisme tahap pelindian asam tekanan tinggi, netralisasi dan penghilangan pengotor serta presipitasi selektif harus diteliti secara mendalam untuk memilih parameter kunci yang sesuai seperti konsentrasi asam, temperatur dan waktu pelindian, presipitasi selektif. Sementara itu, dibutuhkan cara yang efisien untuk mengurangi air pada produk nikel dan kobalt sehingga dapat menghemat biaya transportasi (Yang, 2013). Selain itu, asam nitrat dan asam klorida juga digunakan sebagai media pelindian selama pelindian asam tekanan dalam penelitian terbaru. Pelindian tekanan asam nitrat atau nitric acid pressure leaching (NAPL) telah dipatenkan pada 2008 oleh Chengyan dkk.. Mereka menunjukkan bahwa asam nitrat dapat digunakan sebagai media pelindian pada pelindian dengan tekanan untuk mengolah bijih nikel laterit yang mengandung magnesium tinggi akan tetapi penggunaan asam nitrat diperlukan teknologi tambahan untuk mengolah hasil sampah larutan setelah prosespelindian. Pertama, bijih laterit nikel magnesium tinggi dihaluskan ke ukuran partikel $75 \mu \mathrm{m}(\geq 80 \%)$. Kedua, campuran asam nitrat dan bijih nikel laterit dengan rasio asam/padatan tertentu dimasukkan ke dalam autoclave untuk pelindian tekanan dalam kondisi proses: konsentrasi asam nitrat 500-1500 kg/ton bijih, rasio cair dan padat 3 sampai 10: 1, temperatur pelindian 120$200^{\circ} \mathrm{C}$, waktu pelindian 30-120 menit, kecepatan putaran 300-500 rpm. Ketiga, memurnikan dan menghilangkan zat besi dengan presipitasi melalui penambahan $\mathrm{MgCl}_{2}$ sebagai media penetral dan mengendalikan $\mathrm{pH}$ 2,5 - 3,5 sehingga menghasilkan konsentrasi besi lebih rendah $0,07 \mathrm{~g} / \mathrm{L}$ dalam larutan pelindian. Keempat, endapan hidroksida selektif dari nikel dan kobalt adalah melalui penambahan $\mathrm{MgCl}_{2}$ sebagai media penetral dan mengendalikan $\mathrm{pH}$ pada 6,5 - 8,0 yang dilarutkan dan diekstraksi untuk mendapatkan produk nikel dan kobalt. Hasil ekstraksi nikel dan kobalt semuanya mencapai 95\% dan magnesium mencapai 98\%. Asam nitrat dapat diperoleh dan digunakan kembali. Ma, Wang, Yang, Yang, dkk. (2013) menggunakan pelindian tekanan asam nitrat serta menggunakan pelindian asam sulfat untuk mengekstraksi nikel dan kobalt dari laterit limonitik Indonesia yang mineral utamanya adalah gutit dan magnetit. Kondisi optimal adalah sebagai berikut: rasio asam/bijih 380 $\mathrm{kg} /$ ton bijih, temperatur pelindian $190^{\circ} \mathrm{C}$, waktu pelindian 60 menit, kepadatan pulp 32,5\%, dan ukuran partikel $150 \mu \mathrm{m}(100 \%)$. Menggunakan proses HPAL, hasil ekstraksi nikel dan kobalt masing-masing hanya $74,5 \%$ dan $72,2 \%$ dan konsentrasi besi dalam cairan pelindian sebesar $12,5 \mathrm{~g} / \mathrm{L}$. Namun, pelindian selektif bijih tercapai, dengan hasil ekstraksi lebih dari $85 \%$ untuk nikel dan kobalt dan hanya $1,80 \mathrm{~g} / \mathrm{L}$ besi yang diekstraksi. Sebaliknya, ada beberapa keuntungan Nitric Acid Pressure Leaching (NAPL) yang signifikan dibandingkan dengan High Pressure Atmospheric Leaching (HPAL). Selain itu, asam residu yang menggunakan NAPL lebih rendah daripada menggunakan HPAL. Asam nitrat bertindak sebagai oksidan selain bertindak sebagai lixiviant, yang berguna untuk pembentukan hematit dan menghasilkan konsentrasi besi rendah dalam larutan hasil pelindian. Dalam proses pelindian NAPL dapat terjadi reaksi (1) sampai (4). Residu pelindian memiliki kandungan besi yang tinggi dan tanpa sulfur, yang cocok sebagai bahan baku pembuatan besi. Ma dkk. (2015) merancang serangkaian uji skala pilot tentang pelindian tekanan asam nitrat untuk lima bijih laterit limonit. Di bawah kondisi pelindian optimal (asam nitrat/bijih $380 \mathrm{~kg} / \mathrm{t}$, ukuran partikel 150 $\mu \mathrm{m}(100 \%)$, kepadatan pulp $32,5 \%$, dan pelindian pada $190^{\circ} \mathrm{C}$ selama 60 menit), hasil ekstraksi untuk nikel dan kobalt adalah masingmasing $84,52 \%$ dan $83,85 \%$. Mereka juga melakukan tes skala pilot tentang pelindian asam nitrat bertekanan untuk tiga bijih yang mengandung magnesium tinggi. $\mathrm{Di}$ bawah kondisi pelindian yang optimal (asam nitrat : 
bijih $800 \mathrm{~kg}: 1$ ton, ukuran partikel $150 \mu \mathrm{m}$ $(100 \%)$, kepadatan pulp $28,5 \%$, dan pelindian pada $150^{\circ} \mathrm{C}$ selama 60 menit, hasil ekstraksi rata-rata nikel dan kobalt adalah $98,22 \%$ dan 99,01\%. Penelitian Zhang dkk. (2015) menggunakan pelindian selektif asam hidroklorat bertekanan untuk mengekstraksi nikel dan kobalt dari bijih laterit saprolit yang mengandung 1,37\% Ni dan 18,8\% Fe. Hasil penelitian menunjukkan bahwa pelindian selektif asam hidroklorat merupakan metode yang layak untuk pelindian nikel secara efisien dari bijih laterit. Kondisi pelindian optimal adalah dengan konsentrasi $\mathrm{HCl} 350 \mathrm{~g} / \mathrm{L}$, rasio larutan/padatan 1,0, temperatur pelindian $150^{\circ} \mathrm{C}$, dan waktu pelindian 90 menit. Dalam kondisi optimal, hasil ekstraksi nikel dan kobalt masing-masing adalah $89,4 \%$ dan $97,3 \%$. Untuk tahap awal pelindian, besi akan larut dalam larutan pelindian melalui reaksi (5), yang diikuti oleh presipitasi gutit melalui reaksi (6). Selanjutnya, kandungan air berkurang dari gutit melalui reaksi (7). Namun, $\mathrm{NiCl}_{2}$ tidak mengendap sebagai oksida, karena presipitasi $\mathrm{FeCl}_{4}{ }^{-}$dalam bentuk $\mathrm{Fe}_{2} \mathrm{O}_{3}$ lebih memungkinkan secara termodinamika daripada presipitasi $\mathrm{Ni}^{2+}$ sebagai $\mathrm{NiO}$. Jadi pelindian asam hidroklorat bertekanan juga telah mencapai pelindian bertekanan selektif.

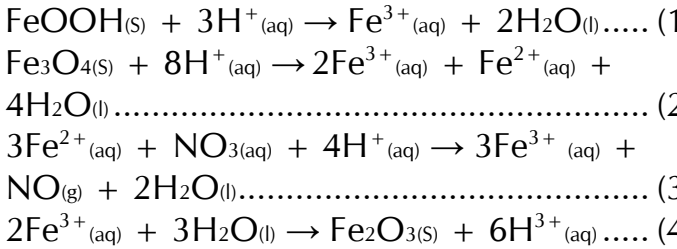

$\mathrm{FeOOH}+4 \mathrm{HCl} \rightarrow \mathrm{FeCl}^{4-}+2 \mathrm{H}_{2} \mathrm{O}+\mathrm{H}^{+}$

$\mathrm{FeCl}^{4-}+2 \mathrm{H}_{2} \mathrm{O} \rightarrow \mathrm{FeOOH}+3 \mathrm{H}^{+}+4 \mathrm{Cl}^{-} . .(6)$

$2 \mathrm{FeOOH} \rightarrow \mathrm{Fe}_{2} \mathrm{O}_{3}+\mathrm{H}_{2} \mathrm{O}$

Sama seperti pada proses pelindian bertekanan tinggi, asam yang paling sering digunakan selama pelindian asam bertekanan atmosfer adalah asam sulfat dengan hasil optimal nikel, kobalt, dan besi sebesar $90 \%$ seperti terlihat pada Gambar 1. Banyak penelitian tentang penggunaan asam klorida, asam nitrat, dan asam organik sebagai bahan pelindian untuk mengekstraksi nikel dari bijih nikel laterit (Wang $d k k ., 2012$; Astuti $d k k ., 2015$; Guo dkk., 2015).

Chen $d k k$. (2015) menggunakan pelindian asam sulfat pada tekanan atmosfer yang mengekstrak bijih laterit dengan kandungan nikel 1,27\% dan kadar besi 39,93\%. Hasil penelitian menunjukkan bahwa ultrasonik memiliki efek signifikan pada ekstraksi nikel dan besi. Kondisi pelindian optimal ditemukan sebagai berikut: ukuran partikel $74 \mu \mathrm{m}(95 \%)$, temperatur pelindian $80^{\circ} \mathrm{C}$, konsentrasi asam sulfat $190 \mathrm{~g} / \mathrm{L}$, rasio padat/cair $20 \%$, waktu pelindian 2 jam, dan kecepatan pengadukan $400 \mathrm{rpm}$. Dalam kondisi yang sama, ekstraksi nikel dan besi mencapai $98,35 \%$ dan $91,28 \%$ dengan aktivitas medan ultrasonik yang bekerja 4 menit setiap 5 menit. Sebaliknya, ekstraksi nikel dan besi hanya $78,84 \%$ dan $80,26 \%$ tanpa bidang ultrasonik. Produk besi dengan kandungan $63,56 \%$ diperoleh dengan presipitasi dan kalsinasi. Tingkat recovery akhir nikel dan besi masing-masing adalah 95,62\% dan 86,50\% seperti terlihat pada Gambar 2.
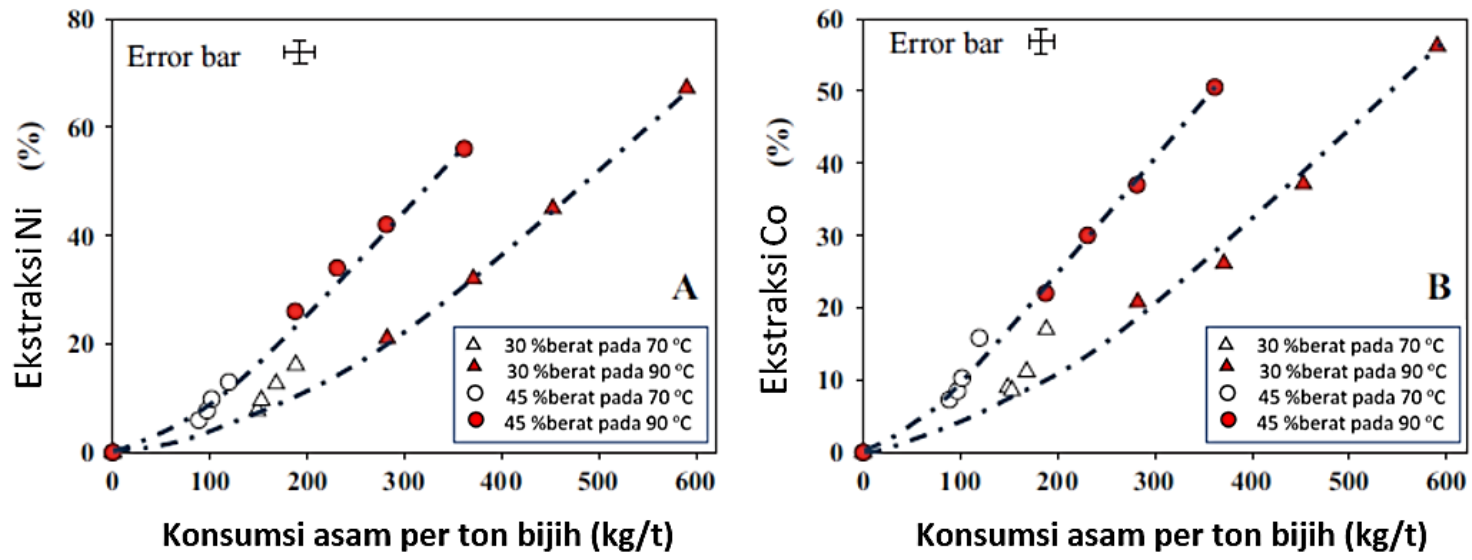

Gambar 1. Konsumsi asam vs. (A) Ni dan (B) Co ekstraksi 30 dan 45 wt.\% SG slurries selama 4 jam leaching pada $\mathrm{pH} 1$ dan temperatur 70 dan $90^{\circ} \mathrm{C}$ (MacCarthy, Addai-Mensah dan Nosrati, 2014). 


\section{Pelindian Asam Bertekanan Atmosfer}

Beberapa penelitian pelindian asam sulfat atmosferik berfokus pada kinetika pelindian nikel dan kobalt (Kursunoglu dan Kaya, 2016). Pengaruh temperatur $\left(70\right.$ vs $\left.90^{\circ} \mathrm{C}\right)$ dan persen padatan (30 vs $45 \%$ ) pada pelindian kinetika nilai $\mathrm{Ni} / \mathrm{Co}$ dan ekstraksi logam gangue $\mathrm{Fe} / \mathrm{Mg}$ dari bijih laterit $\mathrm{Ni}$ kadar rendah $(\sim 1,1 \% \mathrm{Ni})$ pada $\mathrm{pH} 1$ selama 4 jam dan kecepatan pengadukan $600 \mathrm{rpm}$. Pada $70^{\circ} \mathrm{C}$, pemuatan padatan memiliki dampak yang dapat diabaikan pada kinetika pelindian dan hanya 14-18\% $\mathrm{Ni}, \mathrm{Co}, \mathrm{Mg}$, dan 5\% Fe (MacCarthy, AddaiMensah dan Nosrati, 2014). Sementara pada $90^{\circ} \mathrm{C}$, ekstraksi $\mathrm{Ni}$ dan $\mathrm{Co}$ meningkat secara signifikan menjadi $56 \%$ dan $50 \%$ untuk $45 \%$ pemuatan padatan, dan masing-masing $67 \%$ dan $56 \%$ untuk pemuatan padaant $30 \%$. Ini menunjukkan bahwa efek temperatur lebih besar daripada padatan. Pengaruh kecepatan pengadukan dalam kisaran 600-1000 rpm pada perilaku pelindian. Hasil menunjukkan kecepatan pengadukan tidak memiliki efek. Namun, peningkatan reologi tidak memiliki pengaruh yang nyata pada kinetika (MacCarthy $d k k$., 2016). Beberapa peneliti (Li $d k k ., 2012$; Wang dkk., 2012; Guo dkk., 2015) telah menyelesaikan studi tentang bijih laterit yang berbeda pada pelindian asam klorida tanpa tekanan. Pengaruh faktor fisikokimia pada pelindian bijih laterit dalam asam klorida. Kandungan nikel pada bijih $0,87 \%$, dan kadar kobalt $0,061 \%$. Nikel dan kobalt dapat diekstraksi secara efektif pada kondisi pelindian sebagai berikut: konsentrasi asam $8 \mathrm{~mol} / \mathrm{L}$, ukuran partikel $\sim 150 \mu \mathrm{m}(100 \%)$, kecepatan pengadukan $300 \mathrm{rpm}$, temperatur pelindian $80^{\circ} \mathrm{C}$, rasio padat/cair dari $25 \%$ dan waktu pelindian 2 jam. Ekstraksi $\mathrm{Ni}, \mathrm{Co}, \mathrm{Mg}$, dan $\mathrm{Fe}$ dalam kondisi ini adalah masing-masing 92,3\% 61,5\%, 93,5\%, dan 95,5\%, (Li dkk., 2012). Karakterisasi dan atmosfer pelindian asam hidroklorat dari laterit limonit kadar rendah $(0,82 \mathrm{Ni}, 49,92 \% \mathrm{Fe}, \mathrm{Co} 0,078 \% \mathrm{Fe})$ dengan kondisi pelindian optimal adalah sebagai berikut: asam/bijih 1,25, larutan/ padatan 4, temperatur pelindian $80^{\circ} \mathrm{C}$, dan waktu pelindian 2 jam. Hasil ekstraksi $\mathrm{Ni}, \mathrm{Co}$, dan $\mathrm{Fe}$ dalam kondisi ini adalah masing-masing 95,1\% $99 \%$, dan $94,6 \%$ (Gambar 3c) dan SEM-EDS menunjukkan adanya besi dan nikel pada titik 1 dan 2 (Gambar 3a dan 3b). Perilaku disolusi mineral menunjukkan bahwa urutan pelindian sebagai berikut: siderit $\rightarrow$ khrisotil $\rightarrow$ magnetit $\rightarrow$ maghemit $\rightarrow$ gutit $\rightarrow$ hematit $\rightarrow$ kromit $\approx$ ringwodit (Wang $d k k ., 2012$ ).

Oksidasi alkali untuk recovery komprehensif $\mathrm{Mn}$ dan $\mathrm{Mg}$ serta Ni dan Co berdasarkan pelindian asam hidroklorat atmosfer dengan kondisi optimal untuk proses pelindian asam meliputi konsentrasi $\mathrm{HCl} 10 \%$ berat, waktu pelindian 1 jam, $\mathrm{pH} 1$, dan temperatur $30^{\circ} \mathrm{C}$. Dalam kondisi ini, recovery $\mathrm{Ni}, \mathrm{Co}, \mathrm{Mn}$, dan $\mathrm{Mg}$ masing-masing $100 \%, 93,07 \%$, 93,76\%, dan 99,07\%. Dalam kondisi optimal untuk oksidasi alkali termasuk konsentrasi $\mathrm{NaOH} 5 \%$ berat, konsentrasi $\mathrm{H}_{2} \mathrm{O}_{2}$ $10 \%$ berat, konsentrasi $\mathrm{HCl} 10 \%$ berat, dan $\mathrm{pH}$ oksidasi 9 , recovery $\mathrm{Ni}, \mathrm{Co}, \mathrm{Mn}$, dan $\mathrm{Mg}$ adalah masing-masing $100 \%, 95,46 \%$, 92,9\%, dan 98,88\%. Dalam kondisi basa, kemampuan oksidasi $\mathrm{Mn}^{2+}$ melemah, sedangkan kemampuan reduksi meningkat. $\mathrm{H}_{2} \mathrm{O}_{2}$ dapat mengoksidasi $\mathrm{Mn}$ dari keadaan oksidasi +2 ke keadaan oksidasi +4 . $\mathrm{Ni}^{2+}, \mathrm{Co}^{2+}$, dan $\mathrm{Mn}^{2+}$ diendapkan dalam bentuk $\mathrm{Ni}(\mathrm{OH})_{2}, \mathrm{Co}(\mathrm{OH})_{2}$, dan $\mathrm{MnO}_{2}$ melalui penambahan $\mathrm{NaOH}$ yang digunakan untuk mengendalikan $\mathrm{pH}$, meninggalkan $\mathrm{Mg}^{2+}$ dalam cairan. $\mathrm{Ni}$ dan $\mathrm{Co}$ larut dalam asam dan pemisahan mangan terjadi karena $\mathrm{MnO}_{2}$ tidak larut dalam cairan asam encer (Meng $d k k ., 2015)$. Penggunaan asam nitrat sebagai solusi untuk pelindian nikel dari bijih limonit dengan kadar nikel 1,84\% dan kadar besi 23,14\%. Eksperimen dilakukan dengan pelindian agitasi menggunakan 1/50 $\mathrm{g} / \mathrm{mL}$ (rasio padat-cair) dalam gelas ukur $1 \mathrm{~L}$ yang tertutup dalam penangas air yang dikontrol temperaturnya. Dengan kondisi kecepatan pengadukan $200 \mathrm{rpm} /$ menit, konsentrasi asam 2 $\mathrm{mol} / \mathrm{L} \mathrm{HNO}_{3}$, temperatur $80^{\circ} \mathrm{C}$ dan ukuran partikel < $38 \mu \mathrm{m}, 98 \%$ ekstraksi nikel diperoleh selama pelindian 240 menit (Agacayak, Zedef dan Aras, 2016). Dalam penelitian ini, model inti susut diaplikasikan pada hasil percobaan tentang efek temperatur pelindian dalam kisaran $40-90^{\circ} \mathrm{C}$ dan konsentrasi asam nitrat dalam kisaran 0,1-2 $\mathrm{mol} / \mathrm{L}$ pada laju pelarutan nikel. Penggunaan asam nitrat di bawah tekanan atmosfer, dirancang untuk mengekstraksi semua jenis bijih laterit nikel. Bijih ditambang dan kemudian dimasukkan ke pabrik kominusi untuk dihaluskan menjadi $<2 \mathrm{~mm}$. Kemudian dicampur dengan asam nitrat, muatan padatan - 20-30\% dan diumpankan ke tangki pelindian, dipanaskan hingga $110^{\circ} \mathrm{C}$ dengan waktu pelindian 2-6 jam (McCarthy dan Brock, 2015). 

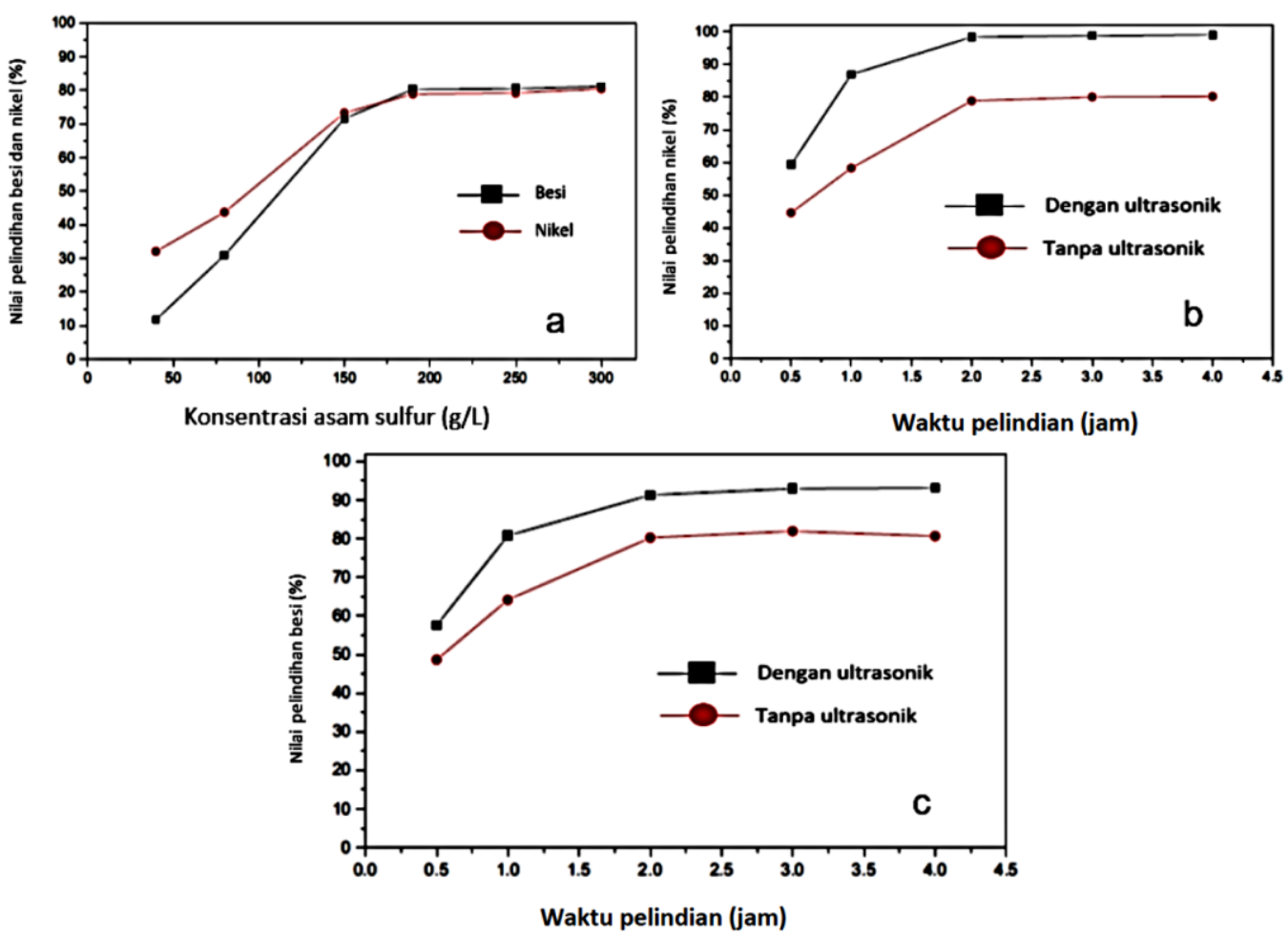

Gambar 2. (a) Pengaruh asam sulfat pada perolehan nikel dan besi dan (b, c) pengaruh ultrasonik dan waktu pelindian pada perolehan nikel dan besi (Chen $d k k ., 2015)$.
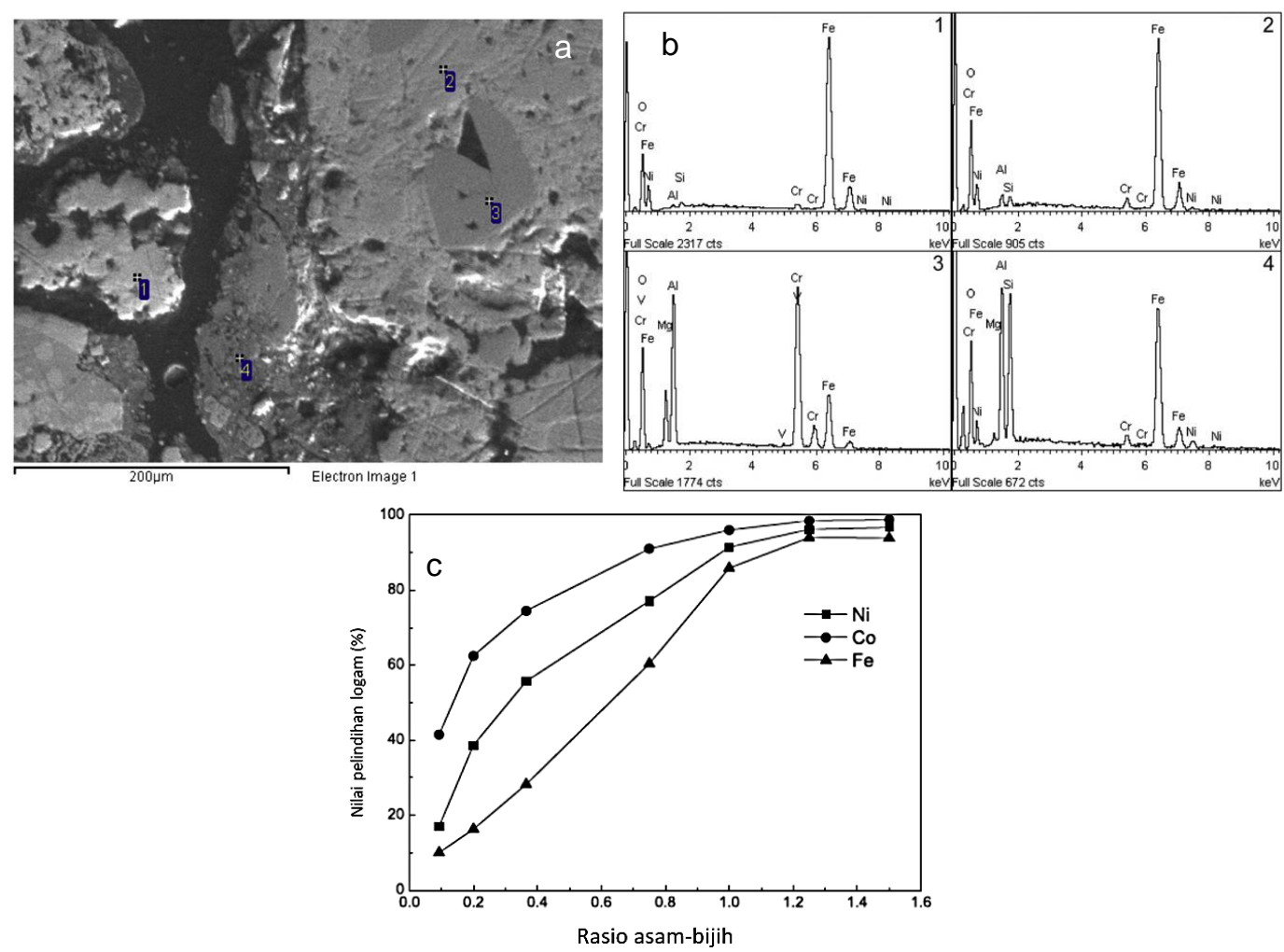

Gambar 3. (a, b) hasil SEM-EDS pada proses pelindian bijih limonit yang terdiri dari 1. magnetit (Fe, Ni dan $\mathrm{Cr}$ ); 2. gutit (Fe, $\mathrm{Ni}$ dan $\mathrm{Cr}$ ); 3. spinel (Al dan $\mathrm{Cr}$ ); 4. mineral lumpur campuran dan gutit dan (c) perolehan nikel, kobalt, dan besi dengan variasi rasio asam pada proses pelindian (Wang dkk., 2012). 


\section{Perbandingan Pelindian Bertekanan dan Bertekanan Atmosfer}

Beberapa penyelidikan tentang kinetika pelindian bijih laterit yang berbeda dalam kondisi pelindian dengan tekanan atmosfer menggunakan asam sitrat telah dilakukan (Astuti dkk., 2015, 2016). Penggunaan asam sitrat sebagai larutan pelindian di bawah tekanan atmosfer untuk ekstraksi nikel bijih saprolitik Indonesia dengan kandungan nikel 1,76\%. Recovery Ni tertinggi 95,6\% dicapai pada kondisi pelindian dengan ukuran partikel bijih 212-355 $\mu \mathrm{m}$, konsentrasi asam sitrat 1 $\mathrm{mol} / \mathrm{L}$, waktu pelindian 15 hari, kepadatan pulp $20 \% \mathrm{~b} / \mathrm{v}$, temperatur pelindian $40^{\circ} \mathrm{C}$ dan kecepatan putaran 200rpm (Astuti $d k k ., 2015)$. Dilaporkan dalam penelitian ini bahwa model inti menyusut sesuai untuk menggambarkan kinetika bijih ini dalam larutan asam sitrat tanpa tekanan. Perbandingan kinetika pelindian asam sitrat bertekanan atmosfer dari bijih saprolitik yang berbeda dengan kandungan nikel masing-masing 1,76\% bijih saprolit sulfida (SS) dan 1,28\% bijih saprolit hidroksida $(\mathrm{SH})$. Efisiensi pelindian maksimum nikel dicapai dari bijih SS dan bijih SH masingmasing $96 \%$ dan $73 \%$ seperti pada Gambar $4 b$ dan 4c. Hasil percobaan menunjukkan bahwa tingkat pelindian nikel dari bijih SS selalu lebih tinggi dari bijih $\mathrm{SH}$ dalam kondisi pelindian yang sama. Sementara itu, ditemukan bahwa serpentin lebih mudah terlindi daripada gutit dan talk dengan menggunakan spektroskopi XRD dan FTIR (Astuti $d k k .$, 2016). Kursunoglu dan Kaya (2015) menyelidiki karakteristik bijih nikel laterit Caldag yang dilindi dengan asam organik berurutan. Setelah dua langkah pelindian, yaitu 8 jam (4 jam +4 jam) pelindian dengan asam organik $(0,5 \mathrm{~mol} / \mathrm{L}$ sitrat $+0,5 \mathrm{~mol} / \mathrm{L}$ oksatik) secara berurutan pada $90^{\circ} \mathrm{C}, 89,63 \% \mathrm{Ni}, 82,89 \% \mathrm{Co}$, dan $69,63 \%$ Fe dilepaskan dari bijih nikel laterit (Ni $1,0813 \%$, Fe 21,916\%, Co 0,0493\%).

Pelindian asam bertekanan menawarkan beberapa keuntungan, seperti tingkat ekstraksi tinggi nikel/kobalt dan efisiensi tinggi. Tetapi ada juga beberapa kelemahan. Kondisi tekanan, lingkungan asam selama tahap pelindian, dan penghapusan netralisasipengotor yang kompleks, menjadikan pelindian asam tekanan memerlukan fasilitas infrastruktur yang kompleks. Selain itu, asam bebas berlebih diperlukan untuk pelindian nikel dan kobalt sejauh mungkin. Proses pelindian asam sulfat bertekanan hanya sesuai untuk mengolah laterit rendah aluminium dan magnesium limonitik rendah. Proses pelindian asam nitrat bertekanan dan pelindian asam klorida dengan tekanan selektif masih belum matang dan membutuhkan optimasi lebih lanjut. Bila dibandingkan dengan pelindian asam tekanan, pelindian asam atmosfer memiliki sedikit peralatan pelindian karena kondisi tekanan atmosfer, dan tingkat ekstraksi nikel relatif rendah. Hasil penelitian menunjukkan bahwa heap leaching tidak efisien dan kurang optimal. Perkembangan proses pelindian asam menguntungkan untuk aplikasi produksi proses hidrometalurgi. Sangatlah penting untuk meningkatkan dan mengoptimalkan proses hidrometalurgi dalam mengekstrak bijih nikel laterit, seiring dengan perkembangan dan pemanfaatan laterit yang semakin luas.
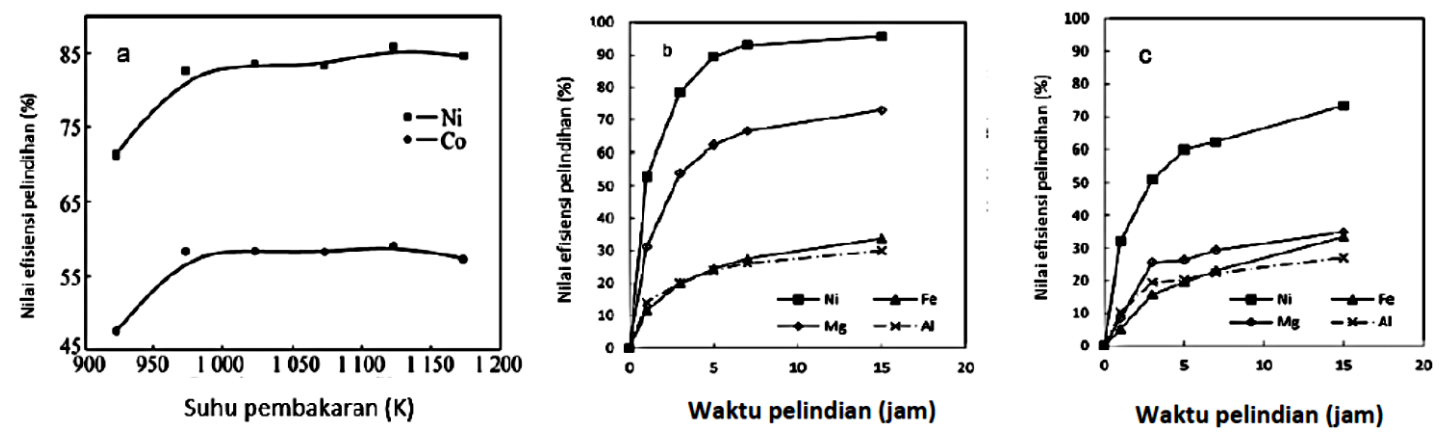

Gambar 4. (a) Efek temperatur pemanggangan dan pelindian pada efisiensi pelindian nikel dan kobalt, (b) dan (c) Perbandingan efisiensi pelindian bijih nikel sulfida dan laterit atau hidroksida (Sheng-li dkk., 2010; Astuti $d k k ., 2016)$. 


\section{TINJAUAN UMUM PROSES PIROMETALURGI PADA PENGOLAHAN BIJIH NIKEL LATERIT}

Metode pirometalurgi dalam ekstraksi bijih nikel laterit terdiri dari rotary kiln-reduksi tungku busur listrik dan menghasilkan nickel matte dan feronikel dalam peleburan reduksi (Warner $d k k .$, 2006). Metode pirometalurgi sebagian besar cocok untuk laterit saprolitik dan laterit garnierit dengan kandungan nikel tinggi (Zevgolis dkk., 2010; Li, Wang dan Wei, 2011; Chen $d k k ., 2015)$.

\section{Kalsinasi dan Penelitian Pirometalurgi}

Laterit direduksi menjadi logam selama proses reduksi dan kemudian produk feronikel dipisahkan dari terak melalui peleburan. Keskinkilic dkk. (2012) mengidentifikasi karakteristik kalsinasi bijih laterit $(1,26 \% \mathrm{Ni}$, $32,6 \% \mathrm{Fe})$ dengan proses kalsinasi, penghilangan air yang terikat secara kimiawi selama transformasi gutit-hematit pada interval $350-700^{\circ} \mathrm{C}$. Hasilnya, temperature $700^{\circ} \mathrm{C}$ harus dipilih sebagai temperaturtemperature kalsinasi untuk menghilangkan air secara efektif yang terikat secara kimiawi. Dalam penelitian Zevgolis dkk. (2010) dipelajari fase transformasi bijih laterit selama pemanasan awal dan reduksi dengan karbon monoksida untuk memahami lebih baik sejauh mana pengaruhnya terhadap reduksi akhir yang diperoleh. Transformasi gutit menjadi hematit diidentifikasi selama pemanasan awal. Metalisasi besi yang lebih tinggi dicapai untuk bijih gutit adalah mineral besi utama dan reduksi naik hingga 95\%, sedangkan yang naik hingga 50\% untuk bijih hematit adalah mineral besi utama. Sangat penting untuk mengontrol pre-reduksi dalam reduksi rotary kiln, karena sangat memengaruhi recovery nikel dan kadar feronikel. Penelitian pada referensi (Bunjaku dkk., 2012) mempelajari pre-reduksi tiga laterit saprolitik yang berbeda dengan berbagai gas pereduksi dan mengeksplorasi hubungan antara reduksibilitas, mineralogi bijih dan gas pereduksi dengan kandungan nikel bijih Kolombia-1, Kolombia-2, dan Mirabela yang digunakan adalah masing-masing 0,76\%, 2,3\%, dan 2,6\%. Bijih nikel tersebut memiliki magnesium tinggi $(14,7-26,6 \%)$ dan silika $(44,9-49,6 \%)$. Ditemukan bahwa tingkat pengurangan dan tingkat oksigen yang dapat dilepas pada $750{ }^{\circ} \mathrm{C}$ dan $900{ }^{\circ} \mathrm{C}$ dalam $\mathrm{CO} / \mathrm{CO}_{2} \quad(72 \%$ : 28\%) lebih rendah dibandingkan dengan percobaan reduksi dalam $\mathrm{H}_{2} / \mathrm{N}_{2} \quad(72 \%$ : 28\%). Reduksibilitas sampel bergantung pada mineralogi dan cara dekomposisi dan rekristalisasi yang dapat dilihat pada Gambar 5. Dengan pengurangan gas bertahap dari hematit menjadi besi logam, serta pengurangan silikat nikel menjadi nikel metal sehingga direkomendasikan untuk menggunakan gas pereduksi $\mathrm{CO}$ agar mencapai metalisasi tertinggi untuk nikel.

Pada penelitian (Pournaderi dkk. (2014) dipelajari efek temperatur, jumlah batu bara, dan waktu reduksi pada pre-reduksi bijih laterit (Ni 1,26\%, Fe 32,6\%) dan dihasilkan bahwa metalisasi Fe optimal hingga $900^{\circ} \mathrm{C}$ dan meningkat dengan cepat pada temperatur yang lebih tinggi. Metalisasi $\mathrm{Ni}$ dan $\mathrm{Co}$ meningkat ketika temperatur meningkat dari 700 menjadi $800{ }^{\circ} \mathrm{C}$, sedikit kenaikan hingga $900^{\circ} \mathrm{C}$ dan kemudian meningkat hingga temperatur $1100^{\circ} \mathrm{C}$. Kandungan nikel dan besi meningkat seiring dengan pertambahan persen konsentrasi batu bara dan peningkatan temperaturtemperatur seperti terlihat pada Gambar 6.

Besi memiliki peran ganda pada temperatur yang lebih tinggi sehingga mempercepat reaksi Boudouard dan pada saat yang sama dapat bereaksi dengan $\mathrm{Ni}$ dan $\mathrm{Co}$ oksida untuk menghasilkan elemen logam (Al-Khirbash, 2015; Rice, 2016). Peningkatan jumlah batubara tidak memengaruhi metalisasi Fe hingga $900^{\circ} \mathrm{C}$ sehingga memengaruhi pengurangan nikel secara merata di semuatemperatur, sementara itu tidak berpengaruh pada metalisasi Co. Pada $1100^{\circ} \mathrm{C}$, reaksi reduksi berlangsung cepat dan berhenti pada $1400^{\circ} \mathrm{C}$. Tetapi reaksi tersebut membutuhkan waktu lebih lama pada temperatur $1000^{\circ} \mathrm{C}$.

$\mathrm{NiO}+\mathrm{Fe}=\mathrm{Ni}+\mathrm{FeO}$

$\mathrm{CoO}+\mathrm{Fe}=\mathrm{Co}+\mathrm{FeO}$ 

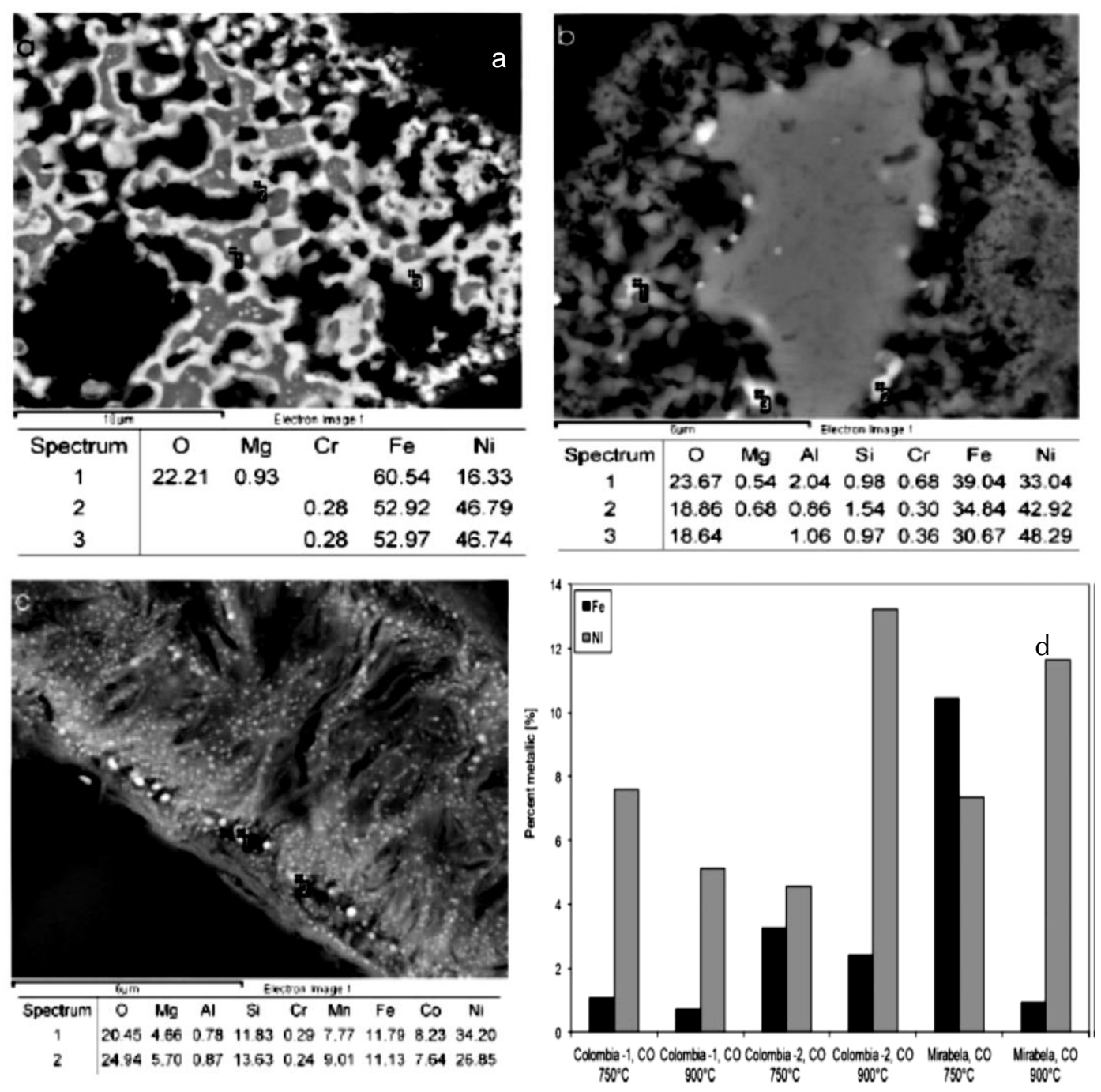

Gambar 5. (a, b, c) Hasil SEM-EDS pada proses pirometalurgi bijih limonit pada Colombia-1 pada temperatur $750^{\circ} \mathrm{C}$, Colombia-2 pada temperatur $900^{\circ} \mathrm{C}$, dan Colombia- 1 pada temperatur $750^{\circ} \mathrm{C}$ dan (d) persen metal dari nikel dan besi dengan variasi jenis material (Bunjaku et al., 2012).
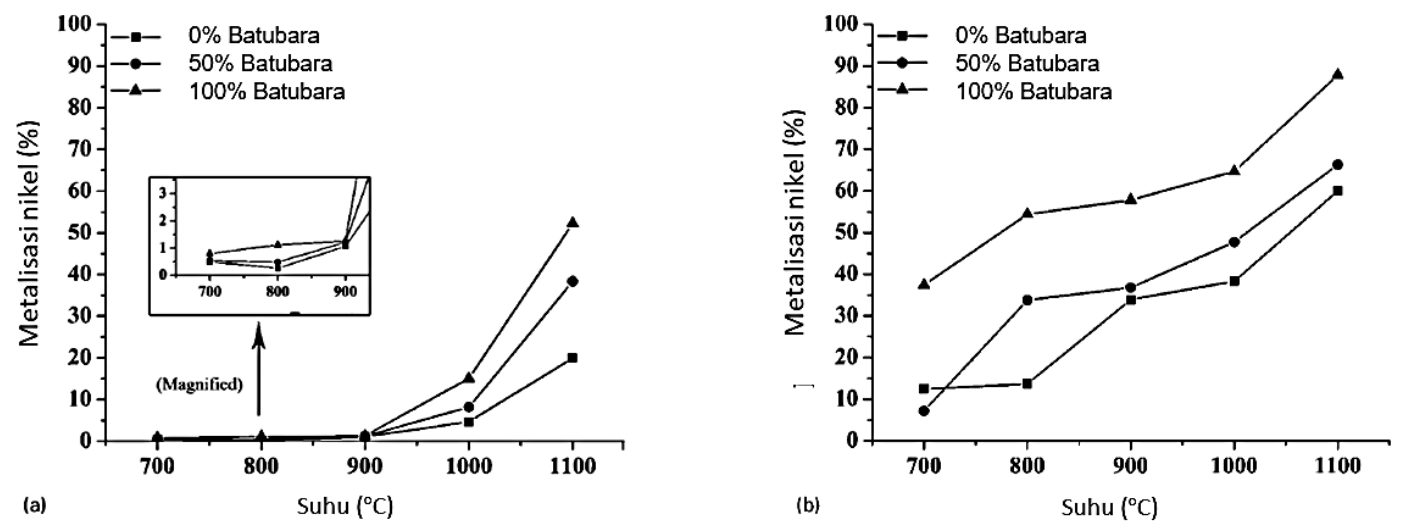

Gambar 6. Efek temperatur dan persen batu bara terhadap metalisasi dari (a) besi dan (b) nikel (Pournaderi $d k k .$, 2014). 


\section{Variasi Fluks}

Berdasarkan proses reduksi berbasis batubara dan pemisahan lebur pada temperatur tinggi, Cao, Xue dan Duan (2016) meneliti pengaruh faktor proses terhadap reduksi bijih laterit dengan kadar nikel rendah 0,78\% dan kadar besi tinggi $46,54 \%$. Hasil penelitian menunjukkan bahwa ketika $\mathrm{CaF}_{2}$ dan kapur ditambahkan secara bersamaan dapat menghasilkan logam yang terpisah dariterak. Dengan rasio mol $\mathrm{C} / \mathrm{O}$ meningkat dari 1,0 menjadi 1,2 dan kandungan $\mathrm{Ni}$ dalam partikel logam meningkat dari 1,37\% menjadi $1,42 \%$, maka hasil recovery $\mathrm{Ni}$ meningkat dari $88,74 \%$ menjadi $92,12 \%$. Selain itu, rasio mol $\mathrm{C} / \mathrm{O}$ yang rendah menahan reduksi oksida besi dan meningkatkan kandungan $\mathrm{Ni}$ dalam logam, sementara tingkat recovery $\mathrm{Ni}$ menurun. Akibatnya, pemilihan aditif dan rasio mol C/O harus dioptimalkan. Li, Wang dan Wei, (2011) mempelajari ekstraksi nikel dari bijih laterit nikel kadar rendah $(\mathrm{Ni}$ 1,09\% dan $\mathrm{Fe}$ $9,12 \%)$ menggunakan metode deoksidasi keadaan padat. Persentase konversi total nikel menjadi nikel logam meningkat dengan cepat seiring meningkatnya $\mathrm{CO}$, dengan $\alpha \mathrm{Ni}$ maksimal $96 \%$ seperti terlihat pada Gambar 7. Selain itu, $\alpha \mathrm{Ni}$ hingga $80 \%$ dapat diperoleh saat menggunakan antrasit sebagai reduktor padat. Menggunakan CO sebagai reduktor, persentase konversi total nikel menjadi nikel logam meningkat dengan meningkatnya temperatur dan waktu, dan kemudian tetap stabil dengan kenaikan lebih lanjut, tetapi menurun secara tibatiba pada temperatur $850^{\circ} \mathrm{C}$ karena transformasi fase. Saat menggunakan antrasit sebagai reduktor, $\alpha \mathrm{Ni}$ umumnya meningkat dengan meningkatnya temperatur reduksi, dan $\alpha \mathrm{Ni}$ meningkat dengan peningkatan waktu reduksi tetapi menurun perlahan seiring peningkatan waktu di atas 80 menit.

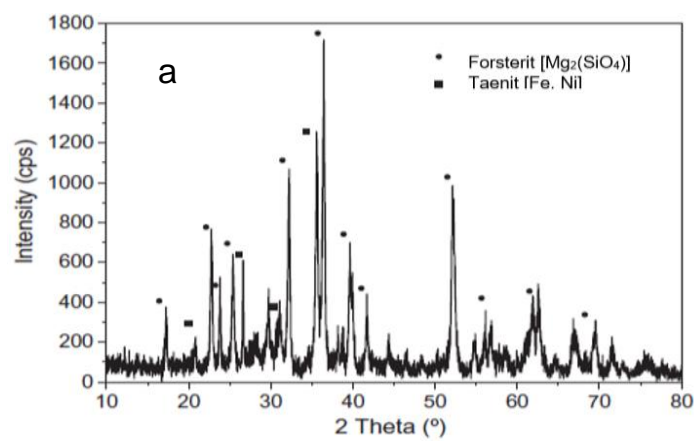

Penelitian tentang karakteristik reduksi nikel dari bijih nikel laterit dengan menggunakan reduktor berbeda menggambarkan pentingnya efek dari jenis/dosis reduktor, temperatur dan waktu reduksi, dan nilai praktis untuk pengembangan metode pirometalurgi. Selama proses reduksi rotary kiln-electric furnace, diperlukan peleburan pada $1500-1600{ }^{\circ} \mathrm{C}$ yang mengarah pada konsumsi energi yang tinggi dari proses tersebut. Kerugian dari intensitas energi tinggi membatasi aplikasi komersialnya untuk mengolah bijih laterit yang mengandung nikel rendah untuk manfaat ekonomi. Proses pirometalurgi adalah teknologi dalam pengolahan mineral yang sudah lama terbukti. Namun, ekstraksi kobalt tidak dapat dicapai. Selain itu, kekurangan dari proses pirometalurgi memiliki ketentuan bijih nikel dalam kadar tinggi dan kebutuhan energi yang besar. Jadi untuk mengurangi konsumsi energi proses pirometalurgi, diperlukan lebih banyak penelitian pada proses ini.

\section{TINJAUAN UMUM REDUKSI SELEKTIF PADA PENGOLAHAN BIJIH NIKEL LATERIT}

Proses hidrometalurgi sangat kompleks dan panjang (Zheng $d k k ., 2014)$, tetapi energinya rendah. Sebaliknya, proses pirometalurgi sederhana tetapi padat energi, dan memiliki persyaratan pada bijih nikel laterit mentah yang mengandung nikel tinggi (Ma, Cui dan Zhao, 2016). Untuk mengatasi keterbatasan proses pirometalurgi, para ahli telah mengusulkan mengganti tahap peleburan dengan pemisahan magnetik untuk recovery partikel feronikel yang dihasilkan selama tahap roasting.

Gambar 7. Hasil XRD (a) dan SEM (b) dari reduksi proses laterit (Li, Wang dan Wei, 2011). 


\section{Awal Mula Reduksi Selektif}

Roasting-pemisahan magnetik adalah proses ekstraksi nikel baru dan menunjukkan potensi yang bagus karena memiliki keuntungan seperti kesederhanaan dan konsumsi energi yang rendah secara bersamaan dan dapat digunakan untuk menangani berbagai jenis bijih laterit (Jiang $d k k$., 2013; Tang $d k k ., 2014$ ). Pada tahap roasting, nikel dan besi direduksi menjadi keadaan logam pada temperatur $1000 \sim 1200$ ${ }^{\circ} \mathrm{C}$. Partikel feronikel dipisahkan dari terak pada tahap pemisahan magnetik setelah hasil roasting dihaluskan. Tingkat recovery nikel umumnya lebih tinggi dari $90 \%$. Proses pemisahan reduksi selektif-magnetik terutama dilakukan untuk meningkatkan kadar nikel produk feronikel. Nikel didapatkan sebanyak mungkin dan metalisasi besi harus ditahan untuk mencapai reduksi selektif yang optimal dan mendapatkan produk feronikel dengan kadar nikel tinggi. Berkenaan dengan selektivitas reduksi, seleksi ini masih kurang sempurna, karena besi harus metalisasi sampai batas tertentu dan bertindak sebagai pembawa nikel (Pickles dkk., 2015). Selain itu, sangat penting untuk memaksimalkan ukuran partikel feronikel sehingga paduan feronikel dapat diperoleh kembali dengan penggilingan berikutnya dan pemisahan magnetik. Zhu (Zhu dkk., 2012) mempelajari ekstraksi bijih laterit limonitik dan saprolitik. Hasil penelitian menunjukkan bahwa peningkatan mineral silikat yang berguna untuk meningkatkan konsentrasi nikel dengan menekan pengurangan oksida besi. Hasil lainnya menunjukkan bahwa penambahan kalsium sulfat sangat mendorong pertumbuhan partikel feronikel. Selain itu, kadar dan tingkat recovery nikel dipengaruhi oleh dosis reduktan. Jiang dkk. (2013) menggunakan proses pemisahan reduksi selektif-magnetik untuk mengolah bijih laterit yang mengandung besi tinggi ( $\mathrm{Ni} 1,49 \%$, $\mathrm{Fe} 34,69 \%$ ), dengan penambahan natrium sulfat. Produk feronikel dengan kadar nikel 9,87\% dan tingkat recovery nikel $90,9 \%$ yang diperoleh pada kondisi bijih laterit direduksi pada temperatur $1200^{\circ} \mathrm{C}$ selama 50 menit dengan penambahan $10 \%$ berat $\mathrm{Na}_{2} \mathrm{SO}_{4}$ dan 2 \% berat batubara. Elliott $d k k$. (2015) mempelajari reduksi selektif bijih limonitik dengan kadar nikel 1,38\% dan kadar besi $45,7 \%$. Digunakan reduksi dua tahap dan proses pertumbuhan termal untuk menghasilkan produk feronikel, sebuah reduksi awal bijih dengan $6 \%$ batubara dan penambahan sulfur $4 \%$ pada $600^{\circ} \mathrm{C}$ selama 1 jam, diikuti oleh pertumbuhan partikel selama 1 jam pada 1000 ${ }^{\circ} \mathrm{C}$. Konsentrat feronikel dengan kadar nikel $4 \%$ dan recovery nikel $93,2 \%$ tercapai. Selain itu, ukuran partikel meningkat dengan meningkatnya temperatur dan waktuproses. Proses reduksi laterit dengan variasi aditif pada dosis $10 \%$ menghasilkan fasa-fasa seperti $\mathrm{F}$ kamacit ([Fe,Ni]), G-taenit ([Fe,Ni]), H-wustit $(\mathrm{FeO}), \quad \mathrm{M}$-forsterite $\left((\mathrm{Mg}, \mathrm{Fe}) 2 \mathrm{SiO}_{4}\right), \quad$ P-spinel $\left(\mathrm{MgFe}_{2} \mathrm{O}_{4}\right), \quad \mathrm{Q}$-troilite (FeS), K-nepheline $\left(\mathrm{Na} 3 \mathrm{MgAl}\left(\mathrm{SiO}_{4}\right)_{2}\right.$ yang terlihat pada Gambar 8.
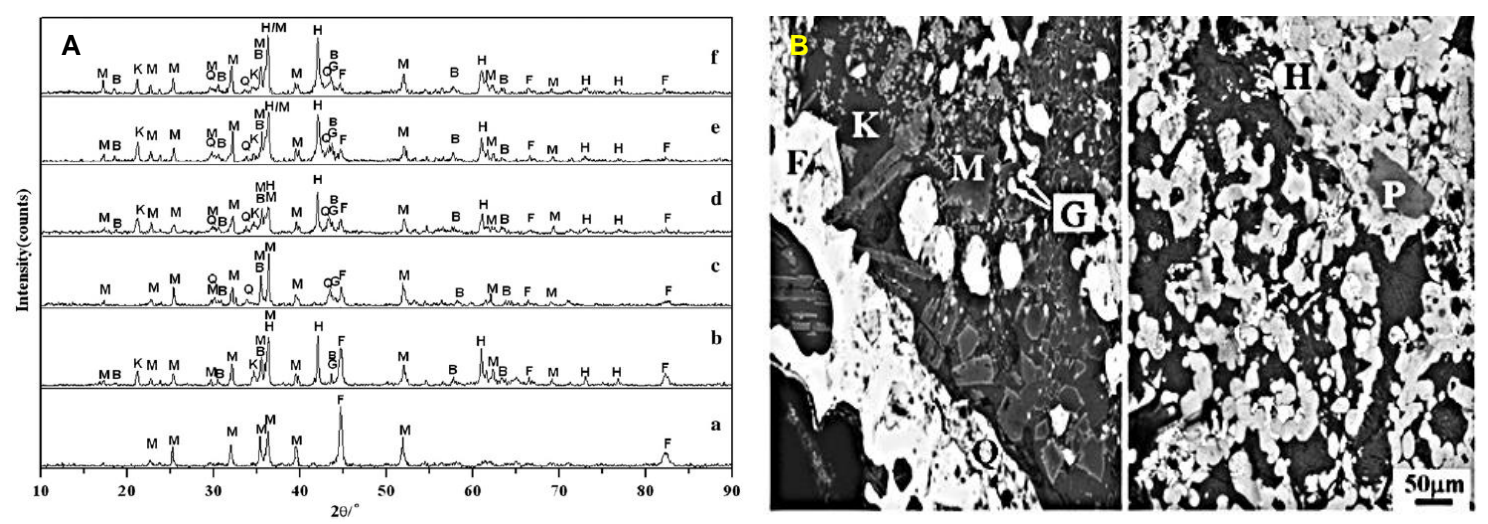

Gambar 8. XRD dari reduksi laterit dengan variasi aditif (a-f) pada dosis 10\% (A) dan SEM sebagai penggambaran bentuk-bentuk fase (B) dengan keterangan F-kamacit ([Fe,Ni]), G-taenit ([Fe,Ni]), H-wustit (FeO), M-forsterit $\left((\mathrm{Mg}, \mathrm{Fe}) 2 \mathrm{SiO}_{4}\right)$, P-spinel $\left(\mathrm{MgFe}_{2} \mathrm{O}_{4}\right)$, Q-troilite (FeS), K-nephelin ( $\mathrm{Na}_{3} \mathrm{MgAl}\left(\mathrm{SiO}_{4}\right)$ 2). (Jiang dkk., 2013) 


\section{Variasi Jenis Aditif}

Elliott (2015) juga mempelajari efek penambahan batubara, belerang, pirit, dan natrium sulfat, dan temperatur reduksi dalam kisaran 1000-1200 ${ }^{\circ} \mathrm{C}$ pada pengurangan selektif limonit dan saprolit. Hasil penelitian menunjukkan bahwa penambahan belerang ke dalam limonit lebih cocok untuk saprolit. Peningkatan penambahan karbon dan sulfur dan temperatur reduksi yang lebih tinggi menyebabkan pembentukan paduan feronikel yang menurunkan kadar nikel. Untuk sampel limonit dengan penambahan sulfur $4 \%$ pada temperatur reduksi $1100^{\circ} \mathrm{C}$ selama 1 jam, ukuran partikel feronikel rata-rata 1,59 $\mu \mathrm{m}$ tercapai, dibaningkan dengan 1,01 $\mu \mathrm{m}$ untuk bijih yang sama dan kondisi reduksi tanpa penambahan sulfur. Sementara untuk saprolit, penambahan sulfur mengurangi ukuran ratarata partikel feronikel. Oleh karena itu penelitian ini mengingatkan bahwa dalam proses mengoptimalkan kondisi reduksi selektif, pemilihan aditif yang sesuai untuk bijih laterit yang berbeda adalah penting. G. Li dkk. (2012) menemukan bahwa $\mathrm{Na}_{2} \mathrm{SO}_{4}$ dapat meningkatkan reduksi nikel laterit dengan membebaskan besi dan nikel dari lizardit tersubstitusi Ni/Fe dan meningkatkan ukuran partikel feronikel untuk secara signifikan meningkatkan kandungan dan laju recovery nikel. Troilit yang dihasilkan dalam sistem reduksi berfungsi sebagai zat pengaktif untuk mempercepat pembentukan fasa peleburan, sehingga memfasilitasi agregasi partikel feronikel selama reduksi selektif nikel dengan menekan metalisasi besi secara sempurna. Jiang $d k k$. (2013) berpendapat bahwa $\mathrm{Na}_{2} \mathrm{SO}_{4}$ dapat terurai menjadi $\mathrm{Na}_{2} \mathrm{O}$ dan $\mathrm{S}$ dalam kondisi 1 atm; dan $\mathrm{Na}_{2} \mathrm{SO}_{4}$ juga direduksi menjadi $\mathrm{Na}_{2} \mathrm{~S}$. S dan $\mathrm{Na}_{2} \mathrm{~S}$ bermanfaat untuk reduksi selektif $\mathrm{Ni}$ karena pembentukan FeS. Liu $d k k$. (2015) menemukan bahwa $\mathrm{Na}_{2} \mathrm{SO}_{4}$ bereaksi dengan $\mathrm{CO}$ dan membentuk $\mathrm{Na}_{2} \mathrm{~S}$, yang kemudian bereaksi dengan $\mathrm{SiO}_{2}$ pada permukaan $\mathrm{FeO}$ untuk menghasilkan $\mathrm{FeS}$ dan $\mathrm{Na}_{2} \mathrm{Si}_{2} \mathrm{O}_{5}$. Akibatnya, lapisan tipis FeS terbentuk di permukaan dan menghalangi kontak antara reduksi gas dan FeO sehingga reduksi besi terjadi. Dengan penambahan $\mathrm{Na}_{2} \mathrm{SO}_{4}$, reduksi selektif bijih nikel laterit oleh $\mathrm{H}_{2}$ dalam reaktor terfluidasi dipelajari oleh $\mathrm{Lu}$ dkk. (2013). Hasil menunjukkan bahwa $\mathrm{Na}_{2} \mathrm{SO}_{4}$ dapat mengontrol kinetika pada bijih laterit dan menunjukkan aktivitas katalitik ketika temperatur mencapai lebih dari $750^{\circ} \mathrm{C}$. Ini juga menunjukkan bahwa waktu reduksi memengaruhi proses reduksi besi oksida. Rao $d k k$. (2016b, 2016a) menyelesaikan penelitian tentang keberadaan $\mathrm{Na}_{2} \mathrm{SO}_{4}$ pada reduksi selektif bijih laterit dari Indonesia. Hasil penelitian menunjukkan bahwa sulfur dari $\mathrm{Na}_{2} \mathrm{SO}_{4}$ akan bereaksi dengan besi dalam bijih laterit untuk membentuk FeS yang dapat menurunkan temperatur fusi karakteristik untuk mendorong pertumbuhan partikel feronikel. Dengan kata lain, $\mathrm{Na}_{2} \mathrm{SO}_{4}$ bermanfaat bagi reduksi selektif dengan mengurangi rasio metalisasi besi melalui sulfida besi oksida. Zhou dkk. (2015) melakukan reduksi bijih laterit nikel kadar rendah dengan penambahan $\mathrm{Na}_{2} \mathrm{~S}, \mathrm{Na}_{2} \mathrm{SO}_{4}$, dan $\mathrm{CaSO}_{4}$. Membandingkan ketiga aditif, $\mathrm{Na}_{2} \mathrm{SO}_{4}$ dapat meningkatkan pertumbuhan feronikel dan kadar nikel dalam feronikel. Ada penelitian yang menunjukkan (Li $d k k$., 2015; Liu dkkl., 2015), CaO cocok sebagai aditif untuk menyesuaikan sifat kebasaan bijih laterit saprolitik selama pemisahan reduksi-magnetik. $\mathrm{CaO}$ yang ditambahkan pada kisaran dosis yang tepat akan menjadi pengotor pada partikel feronikel. Pengzheng $d k k$. (2016) menemukan bahwa $\mathrm{Na}_{2} \mathrm{~S}_{2} \mathrm{O}_{3}$ sebagai aditif akan bertindak sebagai garam alkali dan juga sebagai agen vulkanisasi, berkontribusi terhadap konsentrasi feronikel yang efisien. $\mathrm{Na}_{2} \mathrm{CO}_{3}$ cocok sebagai aditif untuk meningkatkan reduksi dan benefisiasi nikel dengan bereaksi dengan mineral bijih laterit nikel untuk menghancurkan struktur bijih (Guang-hui $d k k ., 2011$ ).

\section{Aspek Penting pada Reduksi Selektif dan Penelitian Terkini}

Realisasi reduksi selektif sangat tergantung pada dua aspek, yaitu mengendalikan atmosfer reduksi yang memiliki korespondensi yang dekat dengan jenis dan dosis reduktor; dan memilih aditif yang sesuai. Aditif yang dapat mengoptimalkan proses reduksi selektif, menghambat reduksi besi, meningkatkan ukuran partikel feronikel, dan meningkatkan efek pemisahan magnetik selanjutnya. Pertumbuhan partikel feronikel dalam tahap pemanggangan reduksi cukup penting untuk menentukan apakah pemisahan efektif partikel feronikel dari pengotor selama tahap pemisahan magnetik selanjutnya dapat dicapai, yang didominasi oleh temperatur 
reduksi, waktu proses dan aditif yang sesuai. Berdasarkan penelitian terbaru dari Nurjaman $d k k$. (2019) terkait penggunaan aditif dalam proses reduksi selektif dilakukan untuk meningkatkan kadar dan recovery nikel dalam konsentrat (Bunjaku dkk., 2011). Salah satu unsur yang dapat digunakan sebagai aditif adalah sulfur, dalam bentuk sodium sulfat (G. Li dkk., 2012; Zhu dkk., 2012; Jiang dkk., 2013; Chen dkk., 2016; Rao dkk., 2016a, 2016b), sodium sulfida (Chen $d k k ., 2016)$, kalsium sulfat (Zhu dkk., 2012; Pickles $d k k$., 2013; Setiawan $d k k ., 2014)$ dan pirit (Harris, Peacey dan Pickles, 2013). Dari beberapa penelitian yang telah dilakukan aditif sodium sulfat memberikan peningkatan kadar dan recovery nikel yang optimal jika dibandingkan dengan penggunaan aditif lainnya, sebagaimana ditunjukkan dalam Tabel 1.

Penambahan dosis natrium sulfat dapat menurunkan metalisasi $\mathrm{Fe}$ dikarenakan terbentuknya senyawa $\mathrm{FeS}$ dengan titik lebur yang rendah, yaitu $980^{\circ} \mathrm{C}$, sehingga meningkatkan laju transfer massa ion-ion logam selama proses reduksi dan menyebabkan partikel feronikel mengalami agregasi (G. Li $d k k ., 2012$; Nurjaman $d k k$., 2019). Ukuran partikel feronikel yang besar akan meningkatkan efektivitas proses pemisahan feronikel terhadap slag/pengotor melalui proses penggerusan yang dilanjutkan dengan separasi magnetik. Selain itu, ada proses reduksi selektif dengan dua tahap pemanasan. Dua tahap pemanasan atau thermal upgrading adalah penambahan proses panas pada proses selektif reduksi. Thermal upgrading adalah teknik yang ditujukan untuk memperlakukan bijih nikel kadar rendah supaya lebih memberikan nilai lebih ketika dilakukan proses benefisiasi fisik. Teknik ini mengacu pada adanya proses reduksi dari nikel dan kobalt yang terkandung dalam bijih limonit untuk menjadi logam yang dapat dipisahkan dari mineral-mineral pengganggu. Berbagai kondisi operasi seperti temperatur, waktu tahan, suasana reduksi, dan penambahan reagen/bahan aditif bertujuan untuk meningkatkan pertumbuhan ukuran partikel logam yang menguntungkan jika dilakukan pemisahan secara magnetik atau flotasi. Inovasi lain dalam kaitannya dengan thermal upgrading telah dilakukan, bijih yang digunakan berupa nikel kadar rendah yang dicampur dengan $6 \%$ batubara dan $4 \%$ sulfur serta menerapkan metode dua tahap thermal upgrading dan di akhiri dengan pemisahan magnet (Elliott, 2015). Tujuan dari metode dua tahap thermal upgrading adalah untuk men-treatment bijih nikel kadar rendah agar didapatkan feronikel yang memiliki kadar dan perolehan kembali logam nikel yang tinggi dengan penggunaan panas yang tidak terlalu tinggi $\left(\leq 1000^{\circ} \mathrm{C}\right)$ dan penambahan sulfur yang relatif sedikit $(\leq 10 \%)$. Tahap pertama pemanasan dilakukan pada bijih yang dicampur batubara dan sulfur pada temperatur $600^{\circ} \mathrm{C}$ selama satu jam untuk mereduksi nikel oksida dengan sempurna dan mendapatkan fasa $\mathrm{Fe}-\mathrm{Ni}-\mathrm{S}$ yang kaya nikel. Kondisi standar dengan tekanan atmosfir, temperatur minimum untuk terjadinya reduksi nikel oksida dengan pereduksi karbon adalah $440^{\circ} \mathrm{C}$, dan optimal pada temperatur $600^{\circ} \mathrm{C}$. Tahap kedua atau disebut pemanasan lanjut dilakukan dengan melakukan treatment panas pada temperatur $1000^{\circ} \mathrm{C}$ dan ditahan satu jam untuk membentuk fasa Fe-Ni-S semi-liquid yang mempermudah berkumpulnya partikel feronikel, selain itu dalam proses pemanasan lanjut juga terjadi pertumbuhan partikel feronikel (Li, Wang dan Wei, 2011). Sesuai dengan penelitian Yang dkk. (2016) menyatakan bahwa pengaruh dua tahap pada laterit dilakukan melalui pengujian DTA seperti pada Gambar 9.

Berdasarkan hasil DTA tersebut, diperlukan adanya tahap pertama untuk menjadikan struktur $-\mathrm{OH}$ menjadi oksida sehingga dapat meningkatkan laju difusi nikel pada besi dan akan mengurangi pembentukan metal besi. Penelitian reduksi selektif dapat dilihat pada Tabel 1 yang menyatakan bahwa reduksi selektif ini merupakan metode baru untuk meningkatkan kadar nikel pada bijih nikel laterit kadar rendah dengan metode penambahan aditif untuk mengurangi temperatur leleh dan pembentukan $\mathrm{FeO}$. 
Tabel 1. Hasil pra-riset (pengaruh aditif dalam reduksi selektif bijih nikel laterit) (Nurjaman $d k k ., 2019)$

\begin{tabular}{|c|c|c|c|c|c|c|c|c|c|c|}
\hline \multirow{2}{*}{$\begin{array}{c}\text { Reduktor } \\
\text { (5\%berat) }\end{array}$} & \multicolumn{6}{|c|}{ Aditif (\%) } & \multicolumn{2}{|c|}{ Grade (\%berat) } & \multicolumn{2}{|c|}{ Recovery (\%) } \\
\hline & $\mathrm{Na}_{2} \mathrm{SO}_{4}$ & $\mathrm{NaCl}$ & $\mathrm{Na}_{2} \mathrm{CO}_{3}$ & $\mathrm{CaSO}_{4}$ & $\mathrm{CaCl}_{2}$ & $\mathrm{CaCO}$ & $\mathrm{Ni}$ & $\mathrm{Fe}$ & $\mathrm{Ni}$ & $\mathrm{Fe}$ \\
\hline & 15 & & & & & & 5,3 & 81,6 & 83,7 & 35,2 \\
\hline & & 5 & & & & & 2,1 & 66,7 & 72,8 & 63,2 \\
\hline ACS-No & & & 10 & & & & 2,5 & 64,9 & 60,7 & 44,3 \\
\hline Sulfur & & & & 15 & & & 3,31 & 64,74 & 53,46 & 29,01 \\
\hline & & & & & 10 & & 2,61 & 66,13 & 28,8 & 21,09 \\
\hline & & & & & & 15 & 1,952 & 63,39 & 50,98 & 45,89 \\
\hline Batubara & 15 & & & & & & 15,1 & 60,6 & 65,5 & 7,3 \\
\hline $\begin{array}{l}\text { Antrasit- } \\
\text { Sulfur }\end{array}$ & & 5 & & & & & 2,64 & 74,1 & 62,96 & 49,37 \\
\hline $\begin{array}{l}\text { kadar } \\
\text { tinggi }\end{array}$ & & & 5 & & & & 2,67 & 83,23 & 55,55 & 83,23 \\
\hline
\end{tabular}
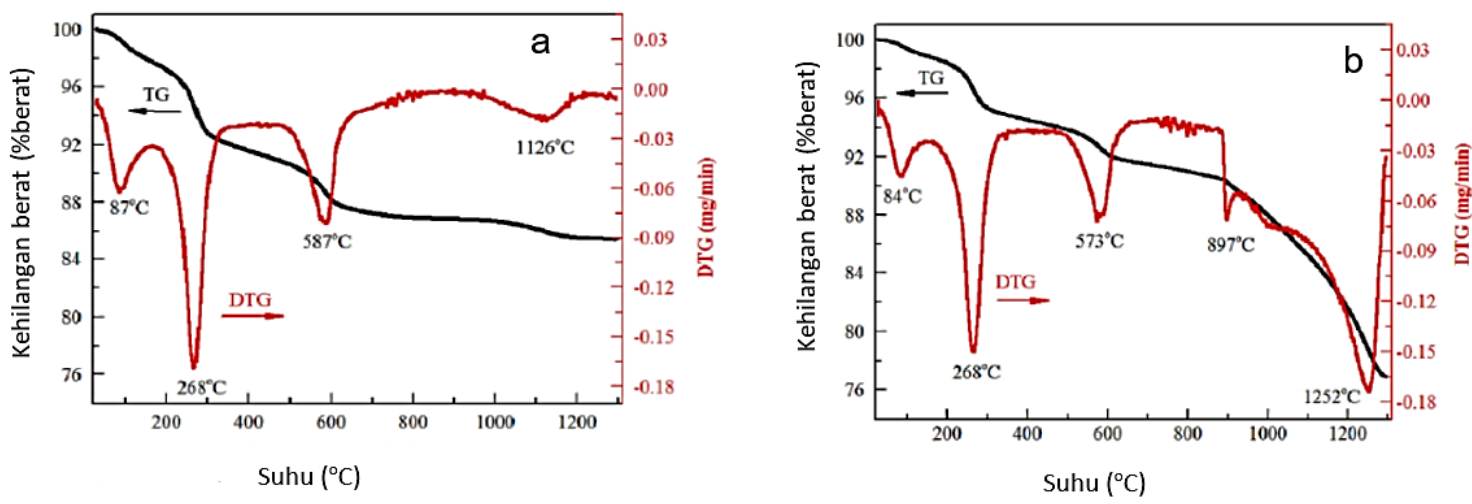

Gambar 9. Diagram differential thermal analysis (a) tanpa $\mathrm{Na}_{2} \mathrm{SO}_{4}$ dan (b) dengan $\mathrm{Na}_{2} \mathrm{SO}_{4}$ (Yang dkk., 2016).

\section{PENGOLAHAN LATERIT DI INDUSTRI}

Pengolahan nikel laterit telah dilakukan dari tahun 1970-an. Laterit kadar rendah tersebut terdiri dari limonit dan saprolit kadar rendah. Secara komersial ada dua proses untuk mengolah laterit kadar rendah, yaitu proses Caron (Ammonia Leaching) dan HPAL/PAL (High Presure Acid Leaching). Pada umumnya proses Caron digunakan untuk memproduksi $\mathrm{NiO}$ sedangkan proses HPAL/PAL untuk memproduksi NiS bahkan nikel dengan kadar 99\%. Di Indonesia akan berdiri Halmahera Persada Lygen di Pulau Obi yang sudah mau beroperasi, juga ada 5 perusahaan yang berencana akan berproduksi pada 2023 dengan jalur proses hidrometalurgi. Pirometalurgi digunakan untuk mengolah saprolit berkadar nikel tinggi ( $\mathrm{Ni}$ 1,8\% bijih Indonesia) untuk memproduksi feronikel (FeNi) atau nickel matte (Ni matte). Di Sulawesi Tenggara sudah ada pabrik pengolahan laterit menggunakan jalur pirometalurgi untuk memproduksi FeNi (feronikel) oleh PT Aneka Tambang di Pomalaa, dan Ni matteoleh PT Vale Indonesia di Sorowako. Perkembangan terbaru setelah 2005, laterit kadar rendah diolah menggunakan jalur proses pirometalurgi untuk memproduksi NPI (Nickel Pig Iron). Selanjutnya NPI digunakan sebagai pengganti FeNi untuk membuat stainless steel. China yang tidak mempunyai sumber daya alam laterit adalah pelopor sekaligus produsen terbesar NPI. Untuk bahan baku NPI, China mengimpor laterit dari Philipina dan Indonesia (Prasetyo, 2016).

Di Cilegon Banten PT INDOFERRO adalah pabrik NPI yang pertama diluar China. PT INDOFERRO mengolah laterit kadar rendah menggunakan blast furnace (BF) untuk memproduksi NPI sejak 2012 (Prasetyo, 2016). Peluang pengolahan laterit sangat besar di Indonesia sehingga penelitian pengolahan laterit ini akan terus berlangsung sampai menemukan hasil yang dapat digunakan sebagai paduan pada peleburan baja tahan 
karat di Indonesia yaitu sebanyak 30 fasilitas pengolahan dan pemurnian (smelter) nikel baru kini sedang dibangun. Bahkan, tak hanya smelter bijih nikel, namun pabrik turunan lainnya seperti stainless steel hingga komponen baterai juga tengah dibangun berdasarkan Webinar "Masa Depan Nikel Indonesia" pada 25 Juni 2020 (Zulhan, 2020).

\section{KESIMPULAN}

Bijih nikel jenis laterit lebih sulit untuk diproses karena kadar nikel yang relatif rendah dan banyak pengotor jika dibandingkan dengan bijih nikel sulfida. Bijih nikel laterit dalam pengolahan hidrometalurgi akan menghasilkan produk nikel dan kobalt sedangkan dalam proses pirometalurgi akan menghasilkan dalam bentuk logam dengan kadar nikel di atas $15 \%$ dan ada elemen pengikut yang lain seperti krom dan kobalt. Selain itu, nikel dapat diekstraksi melalui proses reduksi selektif yang bertujuan untuk menghambat terbentuknya besi oksida. Reduksi selektif akan menghasilkan nikel sebesar 9\% dalam bentuk konsentrat. Prosesproses tersebut memiliki kekurangan dan kelebihan masing-masing, seperti hidrometalurgi dapat menangkap unsur kobalt dan nikel dalam waktu relatif lama sedangkan pirometalurgi secara langsung mereduksi nikel laterit dalam waktu cepat akan tetapi membutuhkan energi yang besar. Adapun proses reduksi selektif memiliki kekurangan yaitu merupakan proses yang tidak langsung untuk mereduksi bijih nikel laterit akan tetapi energi yang dibutuhkan sedikit dan waktu yang singkat.

Oleh karena itu, reduksi selektif merupakan proses alternatif dalam ekstraksi nikel dari bijih laterit untuk menghasilkan konsentrat dengan kadar nikel di atas 5\% yang dapat dikembangkan melalui metode hidrometalurgi untuk mencapai bahan baku baterai berbasis nikel.

\section{UCAPAN TERIMA KASIH}

Penulis mengucapkan terima kasih kepada Prof. Azwar Manaf, Dr. Eng Widi Astuti, dan Fajar Nurjaman S.T., M.T. atas bimbingan dan masukan yang sangat berharga.

\section{DAFTAR PUSTAKA}

Agacayak, T., Zedef, V. dan Aras, A. (2016) "Kinetic study on leaching of nickel from Turkish lateritic ore in nitric acid solution," Journal of Central South University, 23(1), hal. 39-43. doi: 10.1007/s11771-016-3046-8.

Al-Khirbash, S. (2015) "Genesis and mineralogical classification of Ni-laterites, Oman Mountains," Ore Geology Reviews, 65, hal. 199-212. doi: 10.1016/j.oregeorev.2014.09.022.

Astuti, W., Hirajima, T., Sasaki, K. dan Okibe, N. (2015) "Kinetics of nickel extraction from Indonesian saprolitic ore by citric acid leaching under atmospheric pressure," Minerals \& Metallurgical Processing, 32(3), hal. 176-185.

Astuti, W., Hirajima, T., Sasaki, K. dan Okibe, N. (2016) "Comparison of atmospheric citric acid leaching kinetics of nickel from different Indonesian saprolitic ores," Hydrometallurgy, 161, hal. 138-151.

doi: 10.1016/j.hydromet.2015.12.015.

Bunjaku, A., Kekkonen, M., Taskinen, P. dan Holappa, L. (2011) "Thermal behaviour of hydrous nickel-magnesium silicates when heating up to $750^{\circ} \mathrm{C}$," Mineral Processing and Extractive Metallurgy, 120(3), hal. 139-146. doi: 10.1179/1743285511Y.0000000011.

Bunjaku, A., Kekkonen, M., Pietilä, K. dan Taskinen, P. (2012) "Effect of mineralogy and reducing agent on reduction of saprolitic nickel ores," Mineral Processing and Extractive Metallurgy, 121(3), hal. 156-165. doi: 10.1179/1743285512Y.0000000010.

Cao, C., Xue, Z. dan Duan, H. (2016) "Making ferronickel from laterite nickel ore by coalbased self-reduction and high temperature melting process," International Journal of Nonferrous Metallurgy, 05(02), hal. 9-15. doi: 10.4236/ijnm.2016.52002.

Chen, G.-J., Shiau, J.-S., Liu, S.-H. dan Hwang, W.-S. (2016) "Optimal combination of calcination and reduction conditions as well as $\mathrm{Na} 2 \mathrm{SO} 4$ additive for carbothermic reduction of limonite ore," MATERIALS TRANSACTIONS, 57(9), hal. 1560-1566. doi: 10.2320/matertrans.M2016072.

Chen, N., Cao, Z.-F., Zhong, H., Fan, F., Qiu, P. dan Wang, M.-M. (2015) "A novel approach for recovery of nickel and iron from nickel laterite ore," Metallurgical Research \& Technology, 112(3), hal. 306. doi: 10.1051/metal/2015015. 
Chengyan, W., Fei, Y., Yongqiang, C., Yongqiang, Y., Bu, Y., Wei, G., Zhong, W., Shufeng, R., Jun, W., Nianwei, W., Dunfan, L. dan Wu, R. (2008) "Treating method for high magnesium laterite nickel mine." China.

Elliott, R., Rodrigues, F., Pickles, C. A. dan Peacey, J. (2015) "A two-stage thermal upgrading process for nickeliferous limonitic laterite ores," Canadian Metallurgical Quarterly, 54(4), hal. 395-405.

doi: 10.1179/1879139515Y.0000000009.

Elliott, R. S. B. (2015) A study on the role of sulphur in the thermal upgrading of nickeliferous laterite ores. Queen's University.

Guang-hui, L., Ming-jun, R., Tao, J., Qing-qing, H., Tang-ming, S. dan Yuan-bo, Z. (2011) "Innovative process for preparing ferronickel materials from laterite ore by reduction roastingmagnetic separation," The Chinese Journal of Nonferrous Metals, 21(12), hal. 3137-3142.

Guo, Q., Qu, J., Han, B., Zhang, P., Song, Y. dan Qi, T. (2015) "Innovative technology for processing saprolitic laterite ores by hydrochloric acid atmospheric pressure leaching," Minerals Engineering, 71, hal. 1-6.

doi: 10.1016/j.mineng.2014.08.010.

Harris, C. T., Peacey, J. G. dan Pickles, C. A. (2013) "Selective sulphidation and flotation of nickel from a nickeliferous laterite ore," Minerals Engineering, 54, hal. 21-31. doi: 10.1016/j.mineng.2013.02.016.

Jiang, M., Sun, T., Liu, Z., Kou, J., Liu, N. dan Zhang, S. (2013) "Mechanism of sodium sulfate in promoting selective reduction of nickel laterite ore during reduction roasting process," International Journal of Mineral Processing, 123, hal. 32-38.

doi: 10.1016/j.minpro.2013.04.005.

Keskinkilic, E., Pournaderi, S., Geveci, A. dan Topkaya, Y. A. (2012) "Calcination characteristics of laterite ores from the central region of Anatolia," The Journal of The Southern African Institute of Mining and Metallurgy, 112, hal. 877-882.

Kim, J., Dodbiba, G., Tanno, H., Okaya, K., Matsuo, S. dan Fujita, T. (2010) "Calcination of lowgrade laterite for concentration of $\mathrm{Ni}$ by magnetic separation," Minerals Engineering, 23(4), hal. 282-288.

doi: 10.1016/j.mineng.2010.01.005.

Kursunoglu, S. dan Kaya, M. (2015) "Dissolution behavior of Caldag lateritic nickel ore subjected to a sequential organic acid leaching method,"
International Journal of Minerals, Metallurgy, and Materials, 22(11), hal. 1131-1140.

doi: 10.1007/s12613-015-1177-9.

Kursunoglu, S. dan Kaya, M. (2016) "Atmospheric pressure acid leaching of Caldag lateritic nickel ore," International Journal of Mineral Processing, 150, hal. 1-8.

doi: 10.1016/j.minpro.2016.03.001.

Li, B., Wang, H. dan Wei, Y. (2011) "The reduction of nickel from low-grade nickel laterite ore using a solid-state deoxidisation method," Minerals Engineering, 24(14), hal. 1556-1562. doi: 10.1016/j.mineng.2011.08.006.

Li, G., Tangming, S., Mingjun, R., Tao, J. dan Yuanbo, Z. (2012) "Beneficiation of nickeliferous laterite by reduction roasting in the presence of sodium sulfate," Minerals Engineering, 32, hal. 19-26. doi: 10.1016/j.mineng.2012.03.012.

Li, G., Luo, J., Peng, Z., Zhang, Y., Rao, M. dan Jiang, T. (2015) "Effect of quaternary basicity on melting behavior and ferronickel particles growth of saprolitic laterite ores in Krupp-Renn process," ISIJ International, 55(9), hal. 1828-1833. doi: 10.2355/isijinternational.ISIJINT-2015-058.

Li, J., Xiong, D., Chen, H., Wang, R. dan Liang, Y. (2012) "Physicochemical factors affecting leaching of laterite ore in hydrochloric acid," Hydrometallurgy, 129-130, hal. 14-18. doi: 10.1016/j.hydromet.2012.08.001.

Liu, Z., Sun, T., Wang, X. dan Gao, E. (2015) "Generation process of FeS and its inhibition mechanism on iron mineral reduction in selective direct reduction of laterite nickel ore," International Journal of Minerals, Metallurgy, and Materials, 22(9), hal. 901-906. doi: 10.1007/s12613-015-1148-1.

Lu, J., Liu, S., Shangguan, J., Du, W., Pan, F. dan Yang, S. (2013) "The effect of sodium sulphate on the hydrogen reduction process of nickel laterite ore," Minerals Engineering, 49, hal. 154-164. doi: 10.1016/j.mineng.2013.05.023.

Lv, X., Bai, C., He, S. dan Huang, Q. (2010) "Mineral change of Philippine and Indonesia nickel lateritic ore during sintering and mineralogy of their sinter," ISIJ International, 50(3), hal. 380385. doi: 10.2355/isijinternational.50.380.

Ma, B., Wang, C., Yang, W., Yin, F. dan Chen, Y. (2013) "Screening and reduction roasting of limonitic laterite and ammonia-carbonate leaching of nickel-cobalt to produce a highgrade iron concentrate," Minerals Engineering, 50-51, hal. 106-113. doi: 10.1016/j.mineng.2013.06.014. 
Ma, B., Wang, C., Yang, W., Yang, B. dan Zhang, Y. (2013) "Selective pressure leaching of Fe (II)rich limonitic laterite ores from Indonesia using nitric acid," Minerals Engineering, 45, hal. 151158. doi: 10.1016/j.mineng.2013.02.009.

Ma, B., Yang, W., Yang, B., Wang, C., Chen, Y. dan Zhang, Y. (2015) "Pilot-scale plant study on the innovative nitric acid pressure leaching technology for laterite ores," Hydrometallurgy, 155, hal. 88-94.

doi: 10.1016/j.hydromet.2015.04.016.

Ma, X., Cui, Z. dan Zhao, B. (2016) "Efficient utilization of nickel laterite to produce master alloy," JOM, 68(12), hal. 3006-3014. doi: 10.1007/s11837-016-2028-5.

MacCarthy, J., Nosrati, A., Skinner, W. dan AddaiMensah, J. (2016) "Atmospheric acid leaching mechanisms and kinetics and rheological studies of a low grade saprolitic nickel laterite ore," Hydrometallurgy, 160, hal. 26-37. doi: 10.1016/j.hydromet.2015.11.004.

MacCarthy, J., Addai-Mensah, J. dan Nosrati, A. (2014) "Atmospheric acid leaching of siliceous goethitic Ni laterite ore: Effect of solid loading and temperature," Minerals Engineering, 69, hal. 154-164. doi: 10.1016/j.mineng.2014.08.005.

McCarthy, F. dan Brock, G. (2015) "Direct nickel Breakthrough technology," in 4th International Symposium on Processing of Nickel Ores \& Concentrates (Nickel Processing '15). Falmouth, United Kingdom: Curran Associates, Inc., hal. 127-136.

Meng, L., Qu, J., Guo, Q., Xie, K., Zhang, P., Han, L., Zhang, G. dan Qi, T. (2015) "Recovery of Ni, $\mathrm{Co}, \mathrm{Mn}$, and $\mathrm{Mg}$ from nickel laterite ores using alkaline oxidation and hydrochloric acid leaching," Separation and Purification Technology, 143, hal. 80-87.

doi: 10.1016/j.seppur.2015.01.012.

Nurjaman, F., Rahmahwati, A., Karimy, M. F., Hastriana, N., Shofi, A., Herlina, U., Suharno, B. dan Ferdian, D. (2019) "The role of sodiumbased additives on reduction process of nickel lateritic ore," IOP Conference Series: Materials Science and Engineering, 478, hal. 012001. doi: 10.1088/1757-899X/478/1/012001.

Pengzheng, S., Wenguang, D., Song, Y., Shoujun, L. dan Ju, S. (2016) "Influence of sodium thiosulfate in the process of reduction roasting and magnetic separation for nickel laterite ore," Journal of Taiyuan University of Technology, (2), hal. 144-149.
Pickles, C. A., Harris, C. T., Peacey, J. dan Forster, J. (2013) "Thermodynamic analysis of the $\mathrm{Fe}-\mathrm{Ni}-$ $\mathrm{Co}-\mathrm{Mg}-\mathrm{Si}-\mathrm{O}-\mathrm{H}-\mathrm{S}-\mathrm{C}-\mathrm{Cl}$ system for selective sulphidation of a nickeliferous limonitic laterite ore," Minerals Engineering, 54, hal. 52-62. doi: 10.1016/j.mineng.2013.03.029.

Pickles, C. A. dan Elliott, R. (2015) "Thermodynamic analysis of selective reduction of nickeliferous limonitic laterite ore by carbon monoxide," Mineral Processing and Extractive Metallurgy, 124(4), hal. 208-216. doi: 10.1179/1743285515Y.0000000009.

Pickles, C. A., Forster, J. dan Elliott, R. (2014) "Thermodynamic analysis of the carbothermic reduction roasting of a nickeliferous limonitic laterite ore," Minerals Engineering, 65, hal. 3340. doi: 10.1016/j.mineng.2014.05.006.

Pournaderi, S., Keskinkılıç, E., Geveci, A. dan Topkaya, Y. A. (2014) "Reducibility of nickeliferous limonitic laterite ore from Central Anatolia," Canadian Metallurgical Quarterly, 53(1), hal. 26-37.

doi: 10.1179/1879139513Y.0000000099.

Prasetyo, P. (2016) "Sumber daya mineral di Indonesia khususnya bijih nikel laterit dan masalah pengolahannya sehubungan dengan UU Minerba 2019," in Seminar Nasional Sains dan Teknologi 2016. Jakarta: Fakultas Teknik Universitas Muhammadiyah Jakarta, hal. TM008.

Quast, K., Connor, J. N., Skinner, W., Robinson, D. J. dan Addai-Mensah, J. (2015) "Preconcentration strategies in the processing of nickel laterite ores Part 1: Literature review," Minerals Engineering, 79, hal. 261-268. doi: 10.1016/j.mineng.2015.03.017.

Rao, M., Li, G., Zhang, X., Luo, J., Peng, Z. dan Jiang, T. (2016a) "Reductive roasting of nickel laterite ore with sodium sulfate for Fe-Ni production. Part I: Reduction/sulfidation characteristics," Separation Science and Technology, 51(8), hal. 1408-1420.

doi: 10.1080/01496395.2016.1162173.

Rao, M., Li, G., Zhang, X., Luo, J., Peng, Z. dan Jiang, T. (2016b) "Reductive roasting of nickel laterite ore with sodium sulphate for Fe-Ni production. Part II: Phase transformation and grain growth," Separation Science and Technology, 51(10), hal. 1727-1735.

doi: 10.1080/01496395.2016.1166134.

Rice, N. M. (2016) "A hydrochloric acid process for nickeliferous laterites," Minerals Engineering, 88, hal. 28-52.

doi: 10.1016/j.mineng.2015.09.017. 
Setiawan, I., Harjanto, S., Rustandi, A. dan Subagja, R. (2014) "Reducibility of low nickel lateritic ores with presence of calcium sulfate," International Journal of Engineering \& Technology, 14(4), hal. 56-66.

Sheng-li, C., Xue-yi, G., Wan-tang, S. dan Dong, L. (2010) "Extraction of valuable metals from lowgrade nickeliferous laterite ore by reduction roasting-ammonia leaching method," Journal of Central South University, 17(4), hal. 765- 769.

Tang, X., Liu, R., Yao, L., Ji, Z., Zhang, Y. dan Li, S. (2014) "Ferronickel enrichment by fine particle reduction and magnetic separation from nickel laterite ore," International Journal of Minerals, Metallurgy, and Materials, 21(10), hal. 955961. doi: 10.1007/s12613-014-0995-5.

Valix, M. dan Cheung, W. . (2002) “Effect of sulfur on the mineral phases of laterite ores at high temperature reduction," Minerals Engineering, 15(7), hal. 523-530. doi: 10.1016/S08926875(02)00069-9.

Wang, B., Guo, Q., Wei, G., Zhang, P., Qu, J. dan Qi, T. (2012) "Characterization and atmospheric hydrochloric acid leaching of a limonitic laterite from Indonesia," Hydrometallurgy, 129-130, hal. 7-13.

doi: 10.1016/j.hydromet.2012.06.017.

Warner, A. E. M., Díaz, C. M., Dalvi, A. D., Mackey, P. J. dan Tarasov, A. V. (2006) "JOM world nonferrous smelter survey, part III: Nickel: Laterite," JOM, 58(4), hal. 11-20. doi: 10.1007/s11837-006-0209-3.

Yang, S. (2013) "Nickel and cobalt recovery from laterite type nickel ore with high pressure acid leaching technology," Nonferrous Metals(Extractive Metallurgy), (1), hal. 4-7.

Yang, S., Du, W., Shi, P., Shangguan, J., Liu, S., Zhou, C., Chen, P., Zhang, Q. dan Fan, H. (2016) "Mechanistic and kinetic analysis of Na2SO4Modified laterite decomposition by thermogravimetry coupled with mass spectrometry," PLOS ONE. Diedit oleh G. Y, 11(6), hal. e0157369.

doi: 10.1371/journal.pone.0157369.

Zevgolis, E. N., Zografidis, C., Perraki, T. dan Devlin, E. (2010) "Phase transformations of nickeliferous laterites during preheating and reduction with carbon monoxide," Journal of Thermal Analysis and Calorimetry, 100(1), hal. 133-139. doi: 10.1007/s10973-009-0198-x.

Zhang, P., Guo, Q., Wei, G., Meng, L., Han, L., Qu, J. dan Qi, T. (2015) "Extraction of metals from saprolitic laterite ore through pressure hydrochloric-acid selective leaching," Hydrometallurgy, 157, hal. 149-158. doi: 10.1016/j.hydromet.2015.08.007.

Zheng, G., Zhu, D., Pan, J., Li, Q., An, Y., Zhu, J. dan Liu, Z. (2014) "Pilot scale test of producing nickel concentrate from low-grade saprolitic laterite by direct reduction-magnetic separation," Journal of Central South University, 21(5), hal. 1771-1777. doi: 10.1007/s11771-014-2123-0.

Zhou, S., Li, B., Wei, Y., Wang, H., Wang, C. dan Ma, B. (2015) "Effect of additives on phase transformation of nickel laterite ore during lowtemperature reduction roasting process using carbon monoxide," in Battle, T. P. et al. (ed.) Drying, Roasting, and Calcining of Minerals. Cham: Springer International Publishing, hal. 177-184. doi: 10.1007/978-3-319-48245-3_22.

Zhu, D. Q., Cui, Y., Vining, K., Hapugoda, S., Douglas, J., Pan, J. dan Zheng, G. L. (2012) "Upgrading low nickel content laterite ores using selective reduction followed by magnetic separation," International Journal of Mineral Processing, 106-109, hal. 1-7. doi: 10.1016/j.minpro.2012.01.003.

Zulhan, Z. (2020) "Hilirisasi komoditas nikel," in Webinar Keprofesian Teknik Metalurgi "Masa Depan Nikel Indonesia." Bandung: Ikatan Alumni Teknik Metalurgi ITB. 